\title{
A regional view of the linkages between hydro-climatic changes and deforestation in the Southern Amazon
}

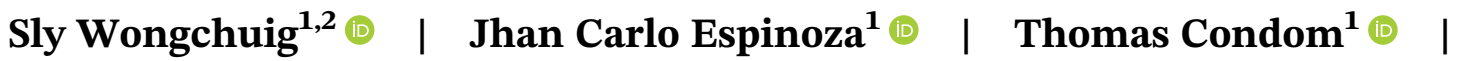

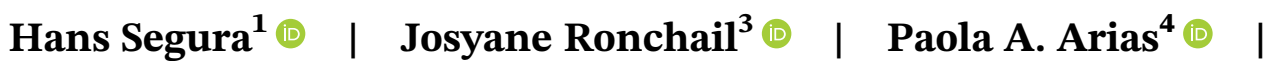

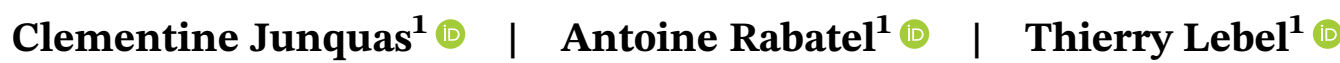

${ }^{1}$ Univ. Grenoble Alpes, IRD, CNRS, Grenoble INP, Institut des Géosciences de l'Environnement (IGE, UMR 5001), Grenoble, France

${ }^{2}$ Instituto de Pesquisas Hidráulicas IPH, Universidade Federal do Rio Grande do Sul UFRGS, Porto Alegre, Brazil

${ }^{3}$ Univ. Paris Diderot and Université de Paris, UMR LOCEAN (Sorbonne Universités-UPMC, CNRS, IRD, MNHN), Paris, France

${ }^{4}$ Grupo de Ingeniería y Gestión Ambiental (GIGA), Escuela Ambiental, Facultad de Ingeniería, Universidad de Antioquia, Medellín, Colombia

\section{Correspondence}

Sly Wongchuig, Univ. Grenoble Alpes, IRD, CNRS, Grenoble INP, Institut des Géosciences de l'Environnement (IGE, UMR 5001), 38000 Grenoble, France. Email: sly.wongchuig-correa@univgrenoble-alpes.fr

\section{Funding information}

French AMANECER-MOPGA project, Grant/Award Number: ANR-18-MPGA0008; MINCIENCIAS, Grant/Award Number: 80740-490-220

\begin{abstract}
In the last four decades, the Southern Amazon (south of $8^{\circ} \mathrm{S}$ ) has shown changes in the spatial and temporal patterns of its hydro-climatic components, leading to drier conditions. Due to climate and land-use changes, this region is considered as a zone under biophysical transition processes. Previous studies have documented a complex interaction between climate and deforestation either on a large-scale or based on limited in situ data, typically covering the Brazilian Amazon. In this study, we analyse the relationships between hydro-climate, the surface waterenergy partitioning and an index of regional forest cover change for the period 1981-2018. Additionally, we discretized three regions covering the Bolivian Amazon and the southern portions of the Peruvian and Brazilian Amazon due to their differences in the evolution of land use. In the Bolivian region, a high ratio of forest cover change, exceeding $40-50 \%$, is related to a significant tendency to become water-limited. This change is associated with decreased rainfall, increased potential evapotranspiration and decreased actual evapotranspiration. Regardless of the region analysed, those that are characterized by a high ratio of forest cover change (>40-50\%) show growing imbalance between increasing potential and decreasing actual evapotranspiration. However, in the Peruvian and Brazilian regions, hydroclimatic conditions remain energy-limited due to minor rainfall changes. The observed differences in surface water-energy partitioning behaviour evidence a complex dependence of both sub-regional (i.e., land cover changes) and large-scale (i.e., strengthening of the Walker and Hadley circulations) conditions. Our findings indicate a clear link between hydro-climatic changes and deforestation, providing a new perspective on their spatial variability on a sub-regional scale.
\end{abstract}

\section{K E Y W O R D S}

forest loss, hydro-climatic variability, water-limited conditions 


\section{INTRODUCTION}

In tropical South America and particularly in the Amazon forest, which spans nine countries and more than 6 millions of square kilometres, climate and vegetation strongly interact, exchanging energy, moisture and momentum in a dynamic equilibrium (Salati and Vose, 1984; Nobre et al., 1991; Salati and Nobre, 1991; Zeng and Neelin, 1999; Zemp et al., 2017). While ongoing environmental changes (including climate change, deforestation and wildfires) are profoundly affecting the biodiversity of this unique ecosystem, a large debate remains about its possible tipping point into a new state with conditions similar to those of a savanna (Nobre and Borma, 2009; Hirota et al., 2011; Davidson et al., 2012; Nobre et al., 2016). Based on model estimates, two thresholds leading to such a tipping have been identified, namely a global warming of $3-4^{\circ} \mathrm{C}$ or deforestation exceeding 40\% (Lenton et al., 2008; Nobre and Borma, 2009; Salazar and Nobre, 2010; Nobre et al., 2016; Aragão et al., 2018; Lovejoy and Nobre, 2018; Brando et al., 2020). However, these results are based on largescale approaches and hypothetical deforestation scenarios (Sampaio et al., 2007; Lawrence and Vandecar, 2015), while the Amazon forest is a complex eco-climatic system where interactions between climate and vegetation occur over a wide range of scales (Cysneiros et al., 2018). For instance, hydro-climatic features over the Amazonia are characterized by a complex spatio-temporal variability related to the large-scale atmospheric circulation (Figueroa and Nobre, 1990; Espinoza et al., 2009a), interactions with the topography (Killeen et al., 2007; Espinoza et al., 2015) and interactions between land surface processes and the atmosphere, including moisture recycling by the forest (Zemp et al., 2017; Staal et al., 2018). Several authors have also found evidence that the hydrological seasonal cycle has changed in the past decades and that even these changes are different according to the regions, with more rainfall and discharge in the north but a longer dry season in the south (Espinoza et al., 2009b; 2019a; García-García and Ummenhofer, 2015; Barichivich et al., 2018; Carvalho Oliveira et al., 2018; Liang et al., 2020). Therefore, in order to better apprehend this complexity, it is necessary to conduct sub-regional scale studies that complement large-scale research and take into account natural and anthropogenic dynamics that may vary significantly from one area to another as well as across scales. Most notably, one factor that has received relatively little attention at sub-regional scale and in a spatially distributed manner is the modification - as the result of either climate change or vegetation changes (natural and anthropic) or both - of some key hydro-climatic variables that control the interactions between climate and vegetation dynamics.
In this respect, the Southern Amazon (south to $8^{\circ} \mathrm{S}$ ) constitutes a peculiar region due to specific climatic characteristics such as its strong rainfall seasonality and the predominance of convective processes partly related to tropical-extratropical interactions (a brief section in the Supporting Information describes the different characteristics of the Southern Amazon with respect to the seasonal cycle of rainfall and the winds circulation, see Figure S1; see also Marengo, 1995; 2004; Espinoza et al., 2009b; Fu et al., 2013; Yin et al., 2014). In addition, vegetation in the Southern Amazon is particularly sensitive to changes in the length of the dry season (Aragão et al., 2008; Costa and Pires, 2010; Gutierrez-Cori et al., 2021), and it has been widely impacted by anthropogenic forcing, especially along a curve that hugs the south-eastern edge of the forest that scientists and resource managers have come to call the 'Arc of Deforestation' (Costa and Pires, 2010; Davidson et al., 2012; Brando et al., 2014; Spracklen and Garcia-Carreras, 2015; Dias et al., 2016; Alves et al., 2017; Damien et al., 2017; Le Page et al., 2017). Large evidences support the coupling between forest lost in the Southern Amazonia and changes in different components of the hydrological cycle, such as evapotranspiration, rainfall amount (Sud et al., 1996; Sampaio et al., 2007; Bathiany et al., 2010; Spracklen et al., 2012; Lawrence and Vandecar, 2015; Leite-Filho et al., 2021), duration of the dry-season and among others (Marengo et al., 2011; Fu et al., 2013; Arias et al., 2015; Debortoli et al., 2015; 2017; Khanna et al., 2017; Wright et al., 2017; Aragão et al., 2018; Agudelo et al., 2019; Leite-Filho et al., 2019; 2021; RuizVásquez et al., 2020). However, most of these studies are based either on limited in situ data covering only the Brazilian Amazon (Fu et al., 2013; Debortoli et al., 2015; 2017; Leite-Filho et al., 2019) or on regional models of coarse resolution $(>50 \mathrm{~km}$ ) (Alves et al., 2017; RuizVásquez et al., 2020). Given the contrasting hydro-climatic changes that have recently been reported in the Southern Amazon due to regional (Marengo, 2004; Espinoza et al., 2013; 2019a; Molina-Carpio et al., 2017) and global processes such as anthropogenic warming (Song et al., 2018), looking at the spatial patterns and temporal dynamics of key hydro-climatic variables in relation to land cover changes is a matter of particular interest.

This study aims to tackle this issue through two angles. The first consists in looking at the co-evolution of the annual precipitation $(P)$ and evapotranspiration (ET, potential and actual) with the surrounding percentage of nonforest vegetation - the idea being to diagnose whether areas of high non-forest vegetation display any significant evolution of $P$ or ET - and, conversely, whether significant evolutions of $P$ or ET may have occurred in areas of little nonforest vegetation. The non-forest vegetation is considered 
here as a proxy for forest loss (see Section 2). Secondly, we investigate whether the decadal co-evolution (for a total of 38 years) of the proportion of non-forest vegetation areas has some implications for the water/energy partitioning by looking at changes in the components of Budyko's theoretical framework.

The procedures used to compute all these variables are detailed in Section 2 and a detailed discussion regarding the validity of these data sets for the Southern Amazon is provided in the Supporting Information.

\section{2 | MATERIALS AND METHODS}

\section{1 | Study region and periods}

We performed analyses for the Southern Amazon Basin (south to $8^{\circ} \mathrm{S}$ ). Over 1992-2018, the Southern Amazon presents an average of $\sim 14 \%$ of deforestation compared to a lower value $(\sim 3 \%)$ for the Northern Amazon (Figure 1b). These averages were computed for areas below $1,000 \mathrm{~m}$ above sea level (m.a.s.l.) and values between Southern and Northern Amazon are statistically significantly different at a confidence level of $99 \%$, which provides an additional reason for focusing our study on the Southern Amazon. This large region is itself divided into three regions of analysis, delimited on the basis of their geopolitical, climate and deforestation characteristics (Eva et al., 2005; Espinoza et al., 2009a; 2019b; Hansen et al., 2013). As shown in Figure 1a, the first region analysed belongs to Bolivian Amazon (hereafter called Bolivian region), the second region belongs to Peruvian Amazon (hereafter called Peruvian region) and finally the third and largest region belongs to Brazilian Amazon (hereafter called Brazilian region). We have taken into account the geopolitical division of these countries, as they have different policies on soil conservation management, so a study at the regional level will also help to generate discussions at this level. Additionally, the areas corresponding to altitudes above $1,000 \mathrm{~m}$. a.s.l. were disregarded from our analyses to avoid the massive topography that affects convection, producing the highest rainfall amounts over the Amazon Basin in the so-called "rainfall hotspots" region (Eva et al., 2005; Espinoza et al., 2015; Chavez and Takahashi, 2017). Our study covers the period 1981-2018 for the hydro-climatic variables and 1992-2018 for the land cover maps. Although the temporal coverage of these data sets is not the same, analyses for years prior to 1992 (non-common period) can still be performed because the land cover maps also contain information on the cumulative changes of past years, that is, before 1992 (see Section 2.3).

\section{2 | Hydrometeorological data sets}

For the hydro-climate analysis of $P$ and ET, we use CHIRPS and GLEAM data sets, respectively. These products have shown an adequate representation of long-term and interannual variability in previous studies in South America (Beck et al., 2017; Wongchuig et al., 2017; Casagrande et al., 2018; da Motta Paca et al., 2019; Moreira et al., 2019; Pan et al., 2020; Espinoza et al., 2019b; Haghtalab et al., 2020).

The evolution of $P$ over 1981-2018 is characterized in terms of amounts (annual totals) and occurrence as measured by the dry day frequency (DDF) and the wet day frequency (WDF), based on the precipitation data set CHIRPS at $5 \mathrm{~km}$ of spatial resolution (Funk et al., 2015). The evolution of ET is assessed by looking at both the potential and actual evapotranspiration (PET and AET, respectively). In order to consider the uncertainty of temporal trend of PET and AET, six land surface, global hydrological models and global model and satellite-based data set were analysed. These models use different configurations for the calculation of PET and AET (see Supporting Information). The data set is from ORCHIDEE, PCRGLOBWB, W3RA, WaterGAP3, HBV-SIMREG and GLEAM. Since most of the temporal trend results of these global models coincide with the results of GLEAM-v3 (Martens et al., 2017), the analyses in the main document are performed using only GLEAM due to: (a) has a longer period (1981-2018 vs. 1972-2012), (b) coincides with the period of the precipitation data set and (c) has a higher spatial resolution $(25 \mathrm{~km}$ vs. $50 \mathrm{~km}$ ). A more detailed discussion on the validation of these products is shown in the Supporting Information.

\subsection{1 | Climate Hazards Group InfraRed Precipitation with Station}

We used the Climate Hazards Group InfraRed Precipitation with Station data (CHIRPS) that was developed by the United States Geological Survey (USGS) and the Earth Resources Observation and Science (EROS) (Funk et al., 2015). This data set is based on merged precipitation models by interpolation of rainfall in situ data. The version 2 (CHIRPS v2) has a spatial resolution of $5 \mathrm{~km}$ and showed an adequate performance for the Amazon Basin when evaluated against ground-based rainfall stations and in situ discharge observations to represent interannual and multi-decadal variability and interannual trends (Wongchuig et al., 2017; Haghtalab et al., 2020; Fassoni-Andrade et al., 2021). 


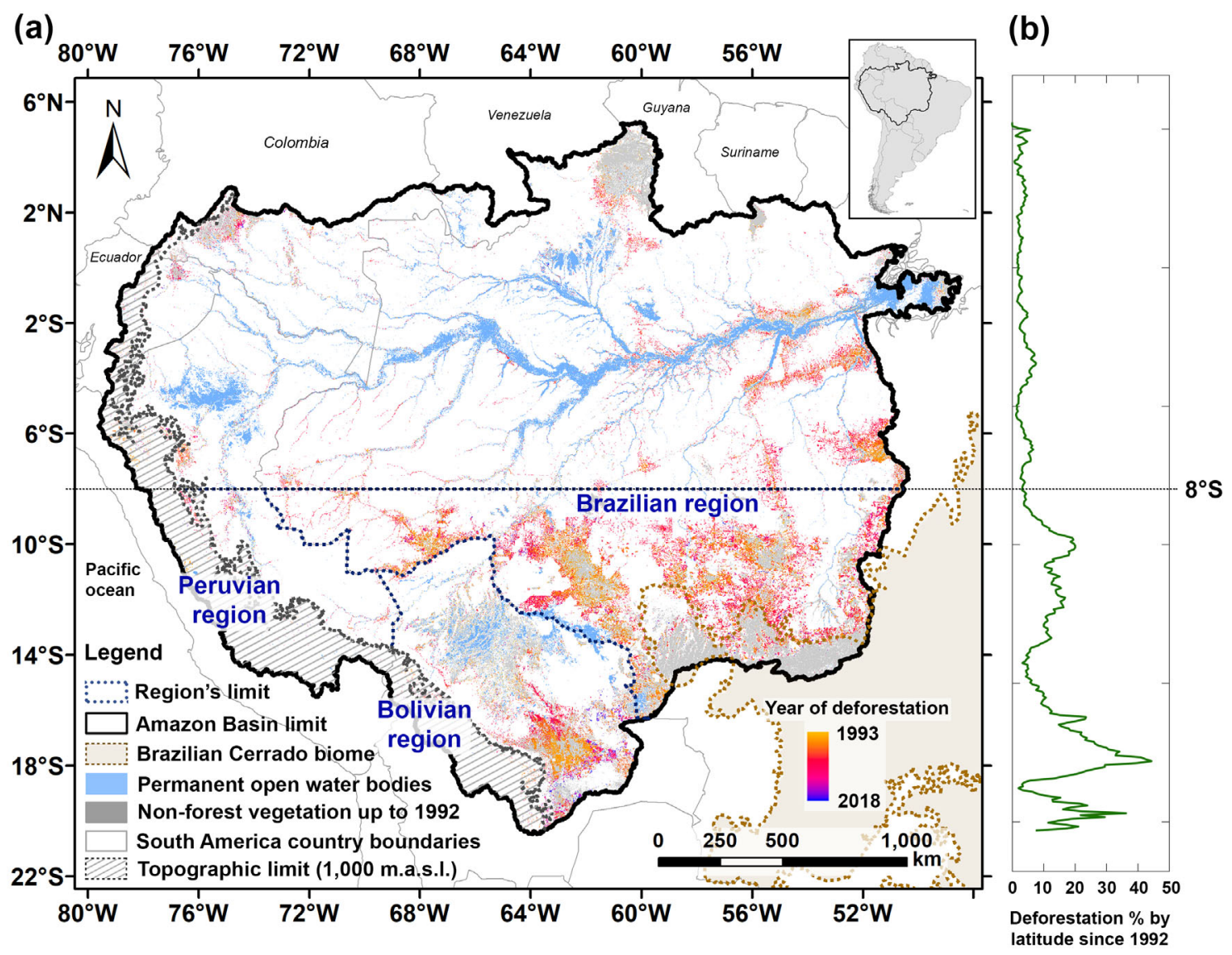

F I G U RE 1 (a) Map of non-forest vegetation up to 1992 (grey) and deforested areas (yellow-red-blue bar colours) for the 1992-2018 period in the Amazon Basin. (b) Percentage of deforestation in relation to latitude and for regions below 1,000 m.a.s.1 [Colour figure can be viewed at wileyonlinelibrary.com]

\subsection{2 | Global Land Evaporation Amsterdam Model}

We used the Global Land Evaporation Amsterdam Model (GLEAM) (Martens et al., 2017), a monthly global evaporation dataset which is based on the Priestley-Taylor equation. This data set-based model was designed to be driven by remote sensing observations only. These observations are primarily derived from microwave sensors, including soil moisture and vegetation optical depth used in GLEAM to constrain the potential evaporation rates. Four types of land covers are possible in GLEAMv3: bare soil, low vegetation, tall vegetation and open water. The vegetation cover is produced using dynamic land cover information based on the MEaSUREs Vegetation Continuous Fields dataset at yearly intervals from 1982 to 2016 itself based on sensors from NOAA-7, NOAA-9, NOAA11, NOAA-14 and Terra. The variations in vegetation status is considered in the stress-factor (used to convert PET to AET) which is based on remote sensed Vegetation Optical Index from CCI-LPRM (Liu et al., 2013) and soil moisture both from remote sensing (ESA CCI SM v2.3; Liu et al., 2012) and land-reanalysis (GLDAS Noah; Rodell et al., 2004) products assimilated into the GLEAM multi-layer soil model. The present paper evaluates the last version (v3.3a) of the product, which updates most components and has a spatial resolution of $25 \mathrm{~km}$.

\subsection{3 | eartH2Observe}

The outputs from the eartH2Observe first water resources reanalysis (WRR) multi-model ensemble, which is a global inter-comparison project produced by different institutions for the period $1979-2012$ at $0.5^{\circ}$ spatial resolution, were used in this research. We used the first version of the WRR based on the current modelling systems of each institution forced with a state-of-the-art atmospheric reanalysis. We only evaluated those models that have PET and AET available, these are ORCHIDEE, PCR-GLOBWB, W3RA, WaterGAP3 and HBV-SIMREG (see Supporting Information). 


\section{3 | Deforestation and non-forest vegetation buffer approach}

Estimates of changes in forest cover were based on the methodology used by (Hansen et al., 2013), where the forest loss is defined as the stand-replacement disturbance of tree cover canopy (complete removal of tree cover canopy at each pixel). Therefore, the forest loss value is assigned for each pixel relative to the first year of the land cover map. To make these estimates, we use the yearly ESA CCI Land Use maps, which cover the period 19922018 and were produced by the European Space Agency (ESA) Climate Change Initiative (CCI) (ESA, 2017; Lamarche et al., 2017).

We used the already provided data set classification of each pixel to determine whether it corresponds to forest or non-forest cover annually, and which is accumulated as deforestation has occurred until the desired analysis period. The ratio of the regional deforested area is computed based on the concept of buffer zones, similar to (Debortoli et al., 2015). The buffer zones approach corresponds to the surrounding neighbourhood around the $300 \mathrm{~m}$ pixels of the ESA CCI Land Use map given by a circular area from each hydro-climatic pixel centroid. Several radii of influence from 25 to $100 \mathrm{~km}$ were assessed in order to find a representative one at regional scale to finally choose the radius of $50 \mathrm{~km}$ for this study (Figure 2a). Non-forested areas (a temporal evolution concept of vegetation cover at time $t$ ) is quantified as a ratio referred as ratio of non-forest vegetation (RNF), therefore the RNF considers the area within the buffer zone (Figure $2 \mathrm{~b}$ ) and refers to the non-forest vegetation cover until each period. The criteria to compute it was considering two periods, before and after 1992, which is when we started to have observations (hereafter called ESA-CCI LC). For periods before 1992, non-forest vegetation cover was considered as grass, shrubs, sparse vegetation and crops (low vegetation types) represented here in the 1992 map. These areas are represented as grey pixels in Figure 1a. Besides, for periods after 1992, changes from forest to these other low vegetation types were considered (Figure 2c), which are represented as pixels in the orange, red and violet colour palette in Figure 1a. These areas do not overlap with the nonforest vegetation cover before 1992 because, by definition, these areas should have been covered by forest in 1992.

In addition, the RNF is divided in classes of $10 \%$ for this investigation (see Section 3.1). Here we highlight that for the analyses made in this manuscript, the $40 \%$ threshold is used for defining low- or high-RNF.

\subsection{DDF and WDF}

The annual DDF is defined as the frequency of days with daily rainfall $(P)$ of less than $1 \mathrm{~mm}$, while the annual WDF is defined as the frequency of day with $P$ greater than $10 \mathrm{~mm}$ (Espinoza et al., 2016; 2019a).

\section{$2.5 \quad$ Kendall trend test}

To compute temporal trends of hydro-climatic variables over the last four decades, we assess the rank-based nonparametric Kendall test (Kendall, 1975). We use the Kendall's $\tau$, which is based on counting the number of $(i, j)$ pairs, for $i<j$, that are concordant that is, for which $X_{a, i}-X_{a, j}$ and $Y_{b, i}-Y_{b, j}$ have the same sign. The equation for Kendall's $\tau$ includes an adjustment for ties in the normalizing constant and is often referred to as $\tau$-b.

For column $X_{a}$ in matrix $X$ and column $Y_{b}$ in matrix $Y$, Kendall's $\tau$ coefficient is defined as:

$$
\begin{gathered}
\tau=\frac{2 K}{n(n-1)} \\
K=\sum_{i=1}^{n-1} \sum_{j=i+1}^{n} F\left(X_{a, i}, X_{a, j}, Y_{b, i}, Y_{b, j}\right) \\
F\left(X_{a, i}, X_{a, j}, Y_{b, i}, Y_{b, j}\right)=\left\{\begin{array}{c}
1,\left(X_{a, i}-X_{a, j}\right)\left(Y_{b, i}-Y_{b, j}\right)>0 \\
0,\left(X_{a, i}-X_{a, j}\right)\left(Y_{b, i}-Y_{b, j}\right)=0 \\
-1,\left(X_{a, i}-X_{a, j}\right)\left(Y_{b, i}-Y_{b, j}\right)<0
\end{array}\right.
\end{gathered}
$$

Values of the correlation coefficient can range from -1 to +1 . A value of -1 indicates that one column ranking is the reverse of the other, while a value of +1 indicates that the two rankings are the same. A value of 0 indicates no relationship between the columns. For this study, the significance of statistical tests is evaluated at 95\% $(p<.05)$.

\section{6 | Surface water and energy partitioning}

Following the buffer-based approach (Debortoli et al., 2015) of land use changes and their relations with the climate, the Budyko-like theoretical framework was applied in this study. The closure in this pixel-based approach of surface water and energy partitioning is not constrained by the watershed limits like usual applications; as a consequence, that is, AET can be greater than 
(a)
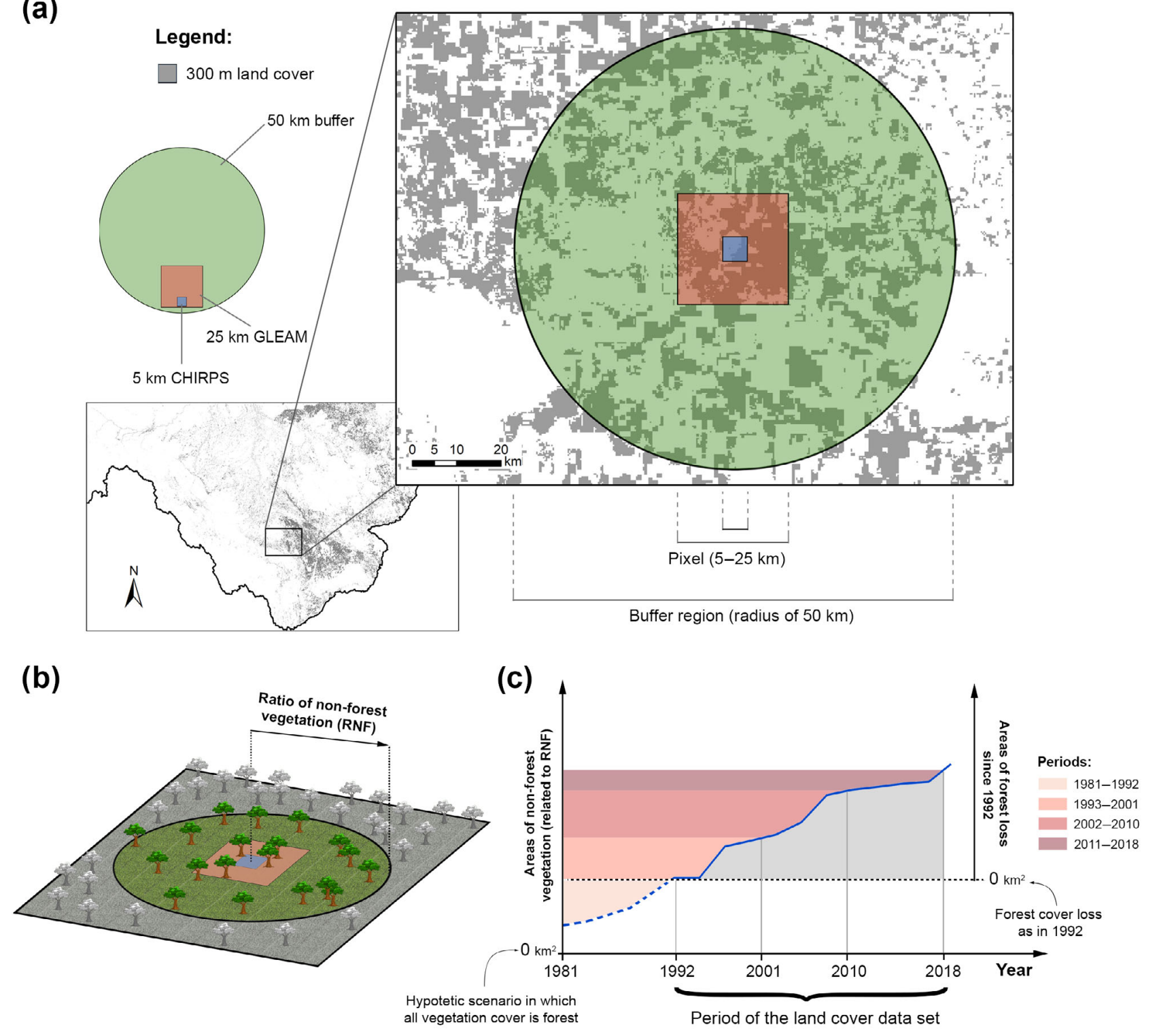

(c)

F I G U RE 2 (a) Illustration of the applied methodology showing an example of the buffer zone of $50 \mathrm{~km}$ radio surrounding a single hydro-climatic pixel of rainfall (CHIRPS-5km) and actual-potential evapotranspiration (GLEAM-25km). The smaller pixels in grey represent the land cover change at 300 of spatial resolution. (b) Illustration of the covered area (in colours) for the ratio of non-forest vegetation (RNF). (c) Schematic representation of temporal area considerations for vegetation non-forest and forest loss since 1992. The blue line represents conceptually the value of land cover change. The periods up to which regional non-forest vegetation were set, are in red scale colours [Colour figure can be viewed at wileyonlinelibrary.com]

$P$ at a pixel scale, which has been aggregated in this analysis to $25 \mathrm{~km}$, which is the coarsest resolution between the GLEAM and CHIRPS data.

According to Budyko's schematic diagram, the vertical water budget is represented in $y$ axis [evaporative index (EI)] and its changes represent the influence of climate, land use and land cover changes. Besides, drier or warmer conditions are shown in $x$ axis [dryness index (DI)] and their changes are in principle only influenced by climatology (Wang et al., 2015; Wang and Zhou, 2016).
As a summary of the methodology, $P$, WDF and DDF variables corresponding to the CHIRPS data were analysed at $\sim 5 \mathrm{~km}$ and their corresponding RNF within the $50 \mathrm{~km}$ radius buffer. For the PET and AET variables corresponding to the GLEAM data, these were analysed at $\sim 25 \mathrm{~km}$ and their corresponding $50 \mathrm{~km}$ radius buffer. The RNF analysis for this first part of this research considers the entire period of non-forest vegetation up to 2018. This means, we calculate the ratio of areas that were already grass, shrub, sparse vegetation and crops 
until 1992 plus the areas that changed from forest in 1992 to these low vegetation covers until 2018.

Besides, for the analysis of the decadal evolution (the total period 1981-2018, divided into four periods) of surface water and energy partitioning, the hydro-climatic variables were aggregated at the coarsest resolution, that is, at $25 \mathrm{~km}$. That is, the DI and the EI were analysed at $25 \mathrm{~km}$ with their corresponding buffer of radius $50 \mathrm{~km}$ and whose RNF values vary with each decade analysed. This means, for the first period (1981-1992) we assumed the representative RNF as the ratio of areas that were already grass, shrub, sparse vegetation and crops until 1992. For the subsequent periods, the RNF has been accumulated as deforestation has occurred until the end of each decade.

\section{3 | RESULTS}

\section{1 | Regional hydro-climatic trends and associated deforestation ratio}

In this subsection, the results are displayed with different panels in Figures 3 and 4: panels 3a, 4a and 4c show the spatial distribution of the Kendall's $\tau$ value of $P$, PET and AET, respectively for the statistically significant pixels. The palette colours indicate that when the trends are on the blue scale, there is a moisture addition in the water balance equation, on the contrary on the red scale is that there is an outflow of moisture from the water balance. The remaining panels show the scatter plot of the Kendall's $\tau$ values of each pixel corresponding to each region associated with the RNF in their respective $50 \mathrm{~km}$ buffer. The boxplots corresponding to each $10 \% \mathrm{RNF}$ interval have been superimposed.

\subsection{1 | Precipitation amount, wet and dry day frequencies}

For the 1981-2018 period, the Bolivian region is characterized by a significant decrease in $P$ in most of its southern area (Figures 3a and S6a), whose Kendall's $\tau$ values are mainly in the range of -0.6 to -0.2 and which is consistent with a reduction in river flows as documented in previous studies (Molina-Carpio et al., 2017; Wongchuig et al., 2017; Espinoza et al., 2019b). This significant reduction in $P$ is systematically observed in areas with RNF values above $40-50 \%$ (Figure 3b,c, left column), meaning that areas with a RNF of at least $40-50 \%$ are always associated with a reduction in $P$, which translates into a systematic diminution in WDF and increase in DDF (Figure 3c,d, left column). Additionally, in the northern part of the Bolivian region, near the border with Brazil, there are regions with a significant increase in $P$ but only associated with low RNF values.

On the other hand, regions of the Peruvian and Brazilian Amazon show zones with significant decrease or increase in rainfall indices ( $P$, WDF and DDF) with no systematic relationship with RNF values, contrary to what is observed in the Bolivian region. A marked decrease in $P$ and WDF is observed in the north-central part of the Brazilian region (Figure 3a), as already reported in previous studies using rainfall stations (Debortoli et al., 2017; Leite-Filho et al., 2019), but not necessarily associated with high values of RNF. On the opposite, the occidental margins of areas with high RNF values, in the Brazilian region in Rondônia state (see Figure 7 for political divisions of states and cities) and close to the Bolivian region, exhibit significant increase in $P$. This could be explained by enhanced convection and an intensified atmospheric moisture transport from the nearby still forested regions, that could be reinforced by the elongated form of this region, as suggested by previous studies (Lawrence and Vandecar, 2015; Khanna et al., 2017; Leite-Filho et al., 2021).

In addition, a part of the Brazilian region corresponds to the Cerrado region, which is described as a Brazilian biome with savanna vegetation (Ratter et al., 1997). In general, the pixels that belong to the Cerrado biome (green dots in Figure 3b-d, right column) do not show significant increases or decreases in precipitation indices. Indeed, pixels showing statistically significant changes in the Cerrado biome represent less than $0.4 \%$ of the total Brazilian region for $P$, WDF and DDF.

\subsubsection{IET and AET}

A significant PET increase is observed over 1981-2018 in most of the Southern Amazon (Figure 4a), particularly in the Bolivian and Peruvian regions and in the eastern Brazilian region. It can be noted that relatively high values of Kendall's $\tau(0.4-0.6)$ occur particularly on the eastern flank of the Andes. This is coherent with the documented increase in temperature over this region as a regional climatic feature (Lavado Casimiro et al., 2013; Seiler et al., 2013). In the Bolivian and Brazilian regions, the highest PET increases are mostly recorded in the highest RNF areas ( $>40 \%$ ), with relatively high Kendall's $\tau$ values $(0.4-0.6)$ but even higher (>0.6) in the highly deforested region of the Southern Bolivian region (Figure 4a,b). Indeed, the land surface temperature increment over tropical deforested areas is related to reduced latent heat flux, due to changes in land cover (Culf et al., 1996; Fisch et al., 2004; Bathiany et al., 2010; Alkama and Cescatti, 2016; Prevedello et al., 2019) and/or 
(a)
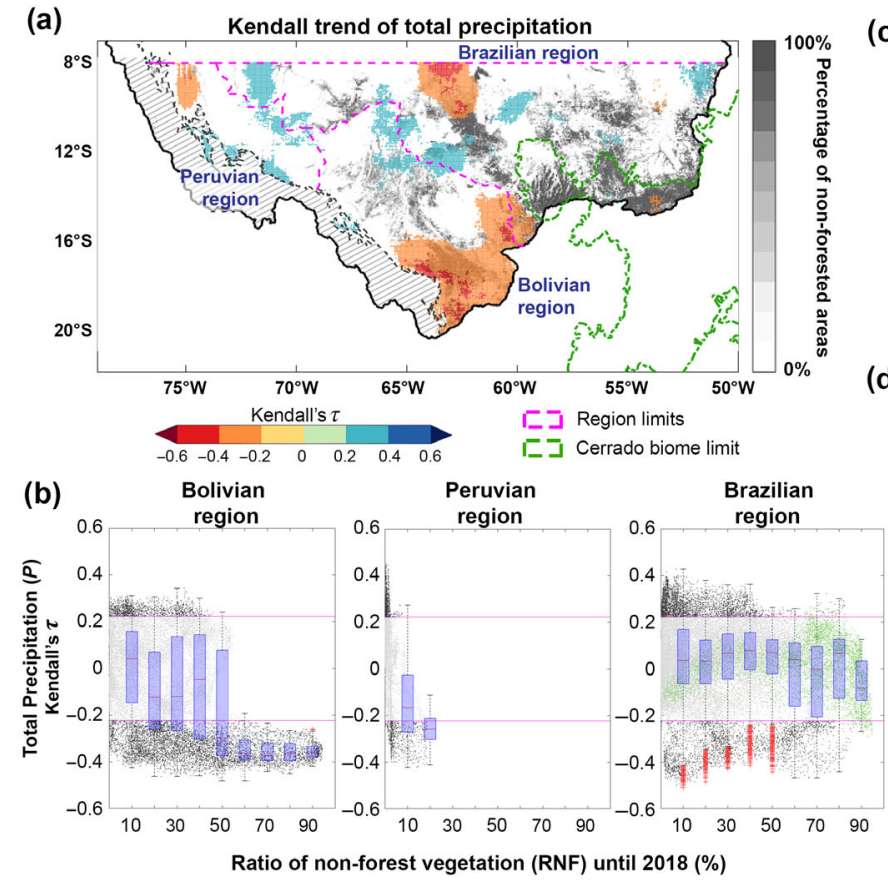

(c)
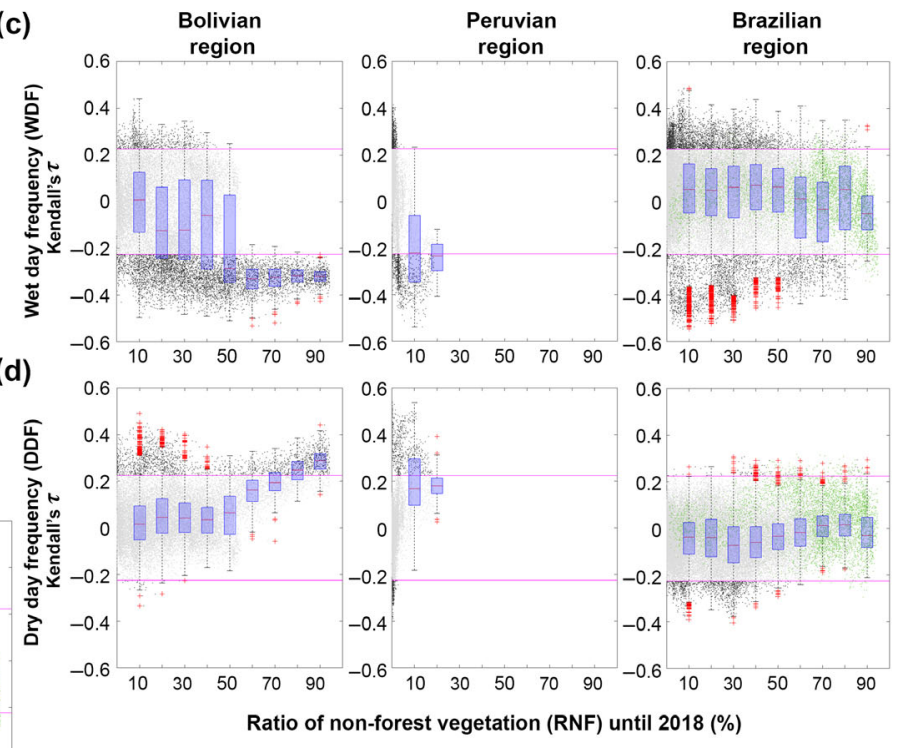

- Significant trend L Limit of significance $(p<.05)$ No significant trend - Cerrado biome

F I G U RE 3 (a) Spatial distribution of the 1981-2018 Kendall coefficient $(\tau)$ showing the significant annual rainfall decrease (red) and increase (blue). The grey scale background indicates the percentage of total non-forested areas as for 2018. Relationships between the ratio of non-forest vegetation (RNF) in percentage up to 2018 and temporal trends [Kendall coefficient $(\tau)$ of the 1981-2018 period] of (b) $P$, (c) WDF and (d) DDF, respectively, in Bolivian (left), Peruvian (middle) and Brazilian (right) regions. The points belonging to the Cerrado biome in Brazilian region are plotted in green. Boxplots for 10\% RNF intervals are superimposed on panels (b-d) [Colour figure can be viewed at wileyonlinelibrary.com]
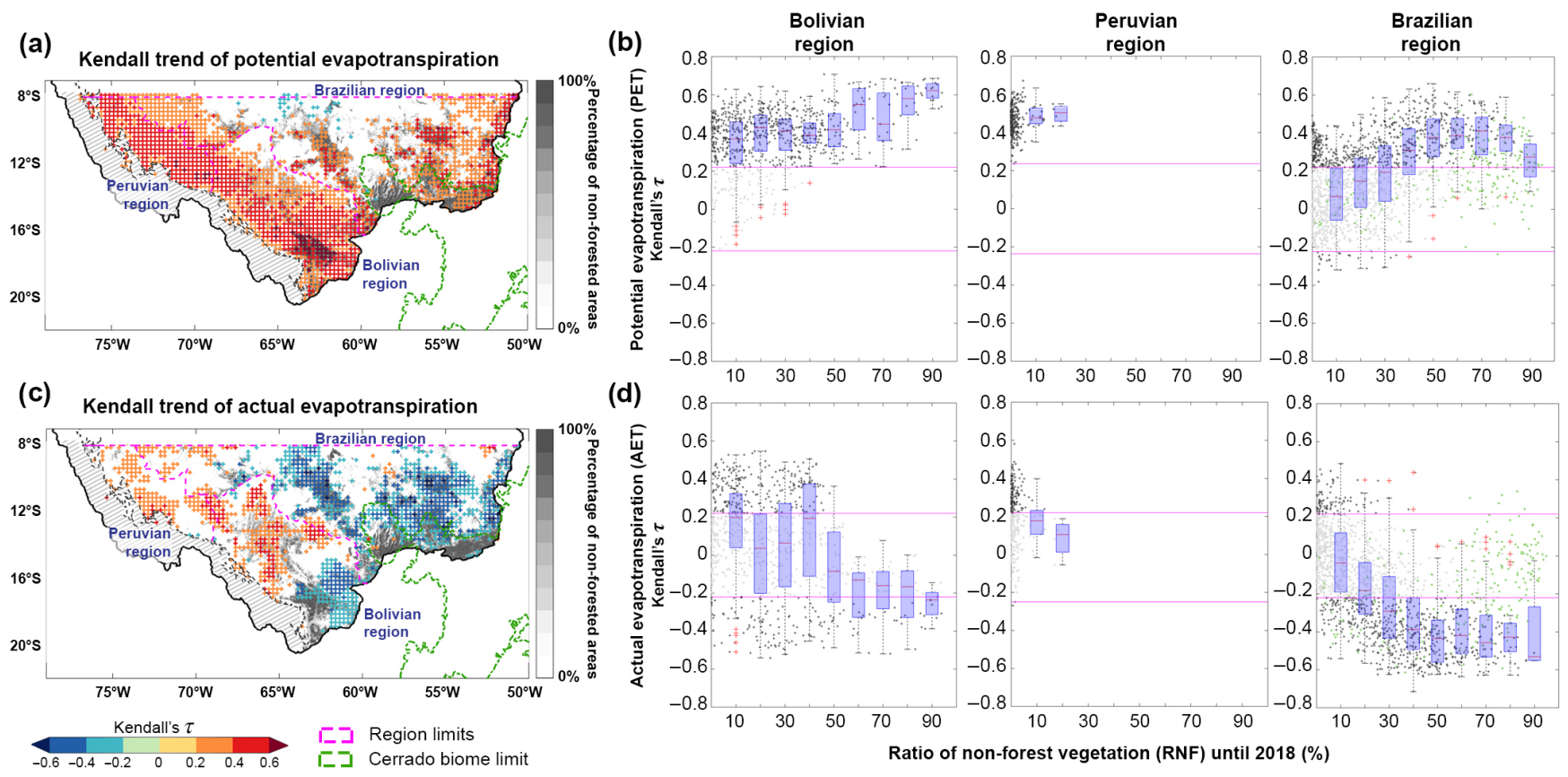

(d)

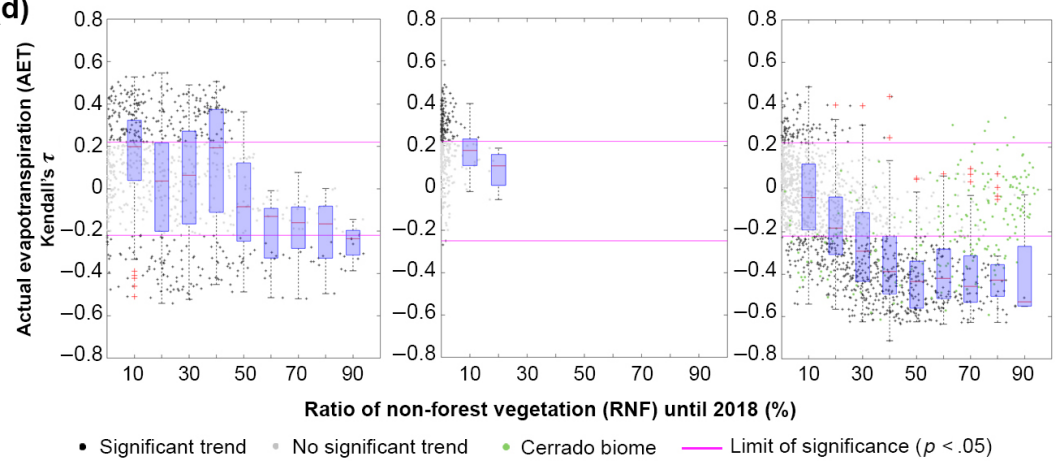

F I G URE 4 Spatial distribution of the 1981-2018 Kendall coefficient $(\tau)$ from the trend analysis of (a) potential and (c) actual evapotranspiration. Significant increase and decrease are indicated in red and blue, respectively. The grey scale background indicates the percentage of total non-forested areas as for 2018. Panels (b) and (d) indicate the relationship between the ratio of non-forest vegetation (RNF) in percentage over up to 2018 and the temporal trend [Kendall coefficient $(\tau)$ of the 1981-2018 period] of PET and AET, respectively, in Bolivian (left), Peruvian (middle) and Brazilian (right) regions. The points belonging to the Cerrado biome in Brazilian region are plotted in green. Boxplots for 10\% RNF intervals are superimposed on panels (b) and (d) [Colour figure can be viewed at wileyonlinelibrary.com] 
increase in radiation due to changes in the patterns of cloudiness (Wang et al., 2009). Note that PET and forest loss data are computed using independent data sources (see Section 2). Remarkably, these results are also valid when five land surface and global hydrological models were analysed (see Figure S3).

On the other hand, spots with significant AET diminution are located in highly and extensively deforested areas (RNF > 40\%) (Figure 4c,d), mostly in the Brazilian region and, to a lesser extent, in the Southern Bolivian region. In the Brazilian region, it can be noted that relatively high values of Kendall's $\tau(-0.6$ to -0.4$)$ are associated with high values of deforestation, including some inland areas with lower values (less than -0.6). It is also interesting to note that this does not occur in the Cerrado region where there are also high values of RNF, which will be discussed later. These findings compare well with those of other studies (Gash and Nobre, 1997; von Randow et al., 2004; 2012; Lee et al., 2005; Baker and Spracklen, 2019; Prevedello et al., 2019; Xu et al., 2020) showing that in deforested areas AET decreases. While, as shown in Figure 4a,b, the capacity of the atmosphere to hold humidity increased in most of the Southern Amazon (PET increase), AET increased in non-deforested areas (Western Amazon) and systematically decreased in large deforested areas (Brazilian and Southern Bolivian regions) (Figure 4c). This is likely explained by the fact that tree canopy in the Amazon has larger access to soil moisture from a deeper soil layer (up to $8 \mathrm{~m}$ ) than grasses, shrubland and sparse vegetation (hereafter called 'low-tree cover', see Supporting Information) and agricultural crops (Nepstad et al., 1994; Kim et al., 2012). This characteristic allows for the transfer of large quantities of water to the atmosphere via transpiration (Lee et al., 2005). Therefore, deforestation favours the energy partitioning towards an increase in the sensible heat flux due to inaccessibility to soil water; moreover, a decrease in $P$ could amplify this effect even in areas with lower RNF. Here again, pixels belonging to the Cerrado biome in the Brazilian region (green dots in Figure $4 b$,d, right column) show a wide spread of increasing and decreasing PET/AET pixels, indicating that there is no significant global trend over this specific biome. However, it is important to note that pixels corresponding to the Cerrado biome region with high values of RNF but no significant AET decrease could be explained by the fact that this region has a high rate of agricultural production (Reis et al., 2017; Pires, 2020). Therefore, the expansion and intensification of irrigated agriculture that was identified in the Cerrado region is likely to influence the AET values (Arantes et al., 2016; Spera et al., 2016). This is also evidenced by the vegetation cover maps used in this research (ESA-CCI LC) where the changes from forest and mainly from low-tree to cropland have been significant in the Cerrado region (see Figure S5f).

\section{2 | Temporal evolution of surface water and energy partitioning for decadal periods}

Here, the relationship between the surface water and energy partitioning and RNF are analysed using a pixelbased Budyko-like theoretical framework approach (see Section 2). In the Budyko framework, the surface water and energy partitioning are characterized by computing an evaporative index $(\mathrm{EI}=\mathrm{AET} / P)$ and a dryness index $(\mathrm{DI}=\mathrm{PET} / P)$. This approach allows for discriminating energy-limited $(\mathrm{DI}<1)$ regions from water-limited (DI $>1$ ) regions. Arguably, a long-term evolution from a neat energy-limited to a neat water-limited regime over large areas might lead to a biome transition. We further discriminate regions with RNF values above (hereafter called 'high-RNF') and below (hereafter called 'lowRNF') 40\% (Figure 5). Note that RNF values evolve every $\sim 10$ years in this analysis. A high-RNF area in 2018 could be due to deforestation (during the land cover data set period, 1992-2018) or pre-existing non-forest vegetation cover. On the other hand, in areas characterized by a strong dynamics of forest loss, passing the RNF threshold of $40 \%$ has been hypothesized as a possible tipping point in terms of bioclimatic feedback (Sampaio et al., 2007; Nobre and Borma, 2009; Nobre et al., 2016). In this perspective, it is worth noting that areas with high-RNF values in the Bolivian region display a systematic decrease in $P$ (Figure 3). This is why RNF is used here as both a spatial pattern descriptor for a given year or period of 10 years and a dynamic descriptor by looking at its evolution over successive 10 -year periods.

\subsection{1 | Bolivian region}

In the Bolivian region, most of the area for the 1981-1992 period is energy-limited (DI in the range of $\sim 0.50-1.0$; Figure 5a left column). However, after 1992, 19\% of the region becomes water-limited (DI in the range of $\sim 1.0$ 1.5), mainly in high-RNF areas (grey circles with black borders), as can be seen from the statistical distribution plotted in red below the $x$ axis of Figure 5a-d. The transition from an energy-limited to a water-limited condition in high-RNF areas is caused by both a PET increase and a $P$ decrease over this region, mainly in southern areas (south of $15^{\circ} \mathrm{S}$ ) (Zhang et al., 2016; Espinoza et al., 2019b). While $P$ and PET evolutions are likely driven by large-scale climatic conditions, the PET 


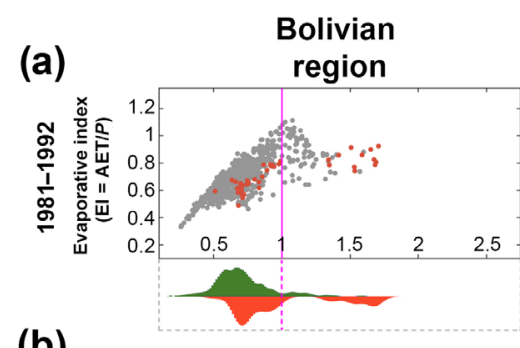

(b)

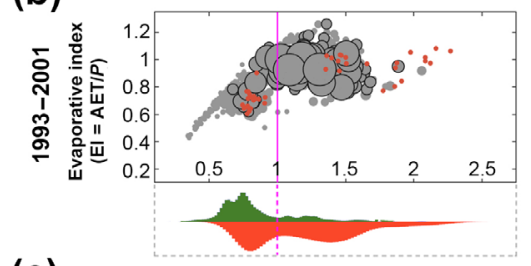

(c)

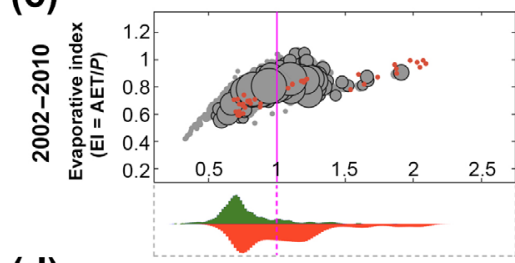

(d)

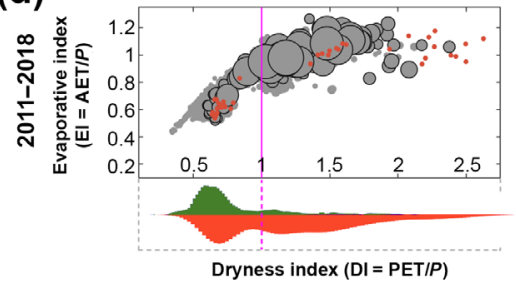

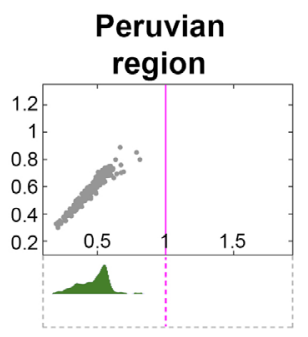
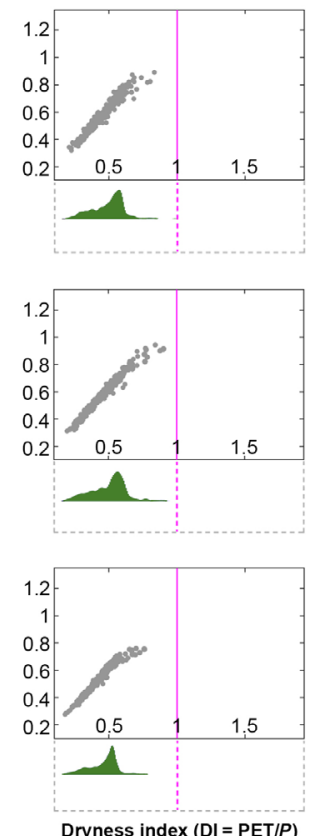
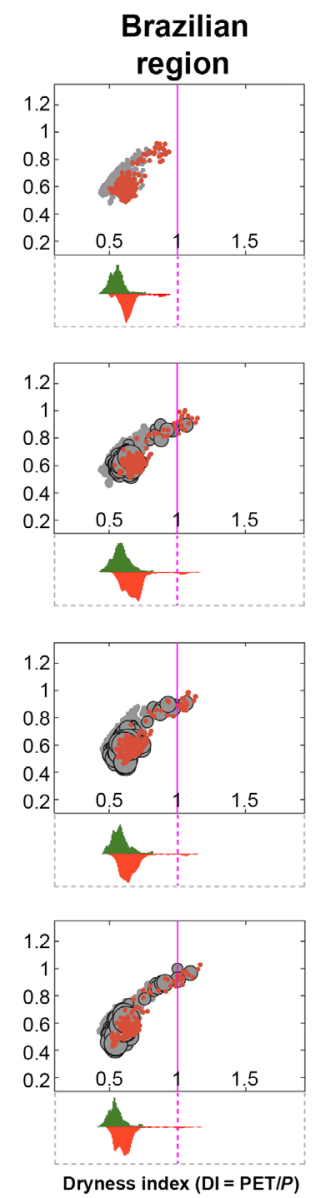

$\geq 40 \%$ of non-forest vegetation areas as for 1992

Energy and water limited boundary

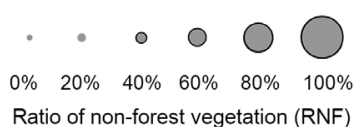

Distribution of indexes with areas:

$1<40 \%$ of non-forest vegetation (low-RNF)

$M \geq 40 \%$ of non-forest vegetation (high-RNF)

(e)

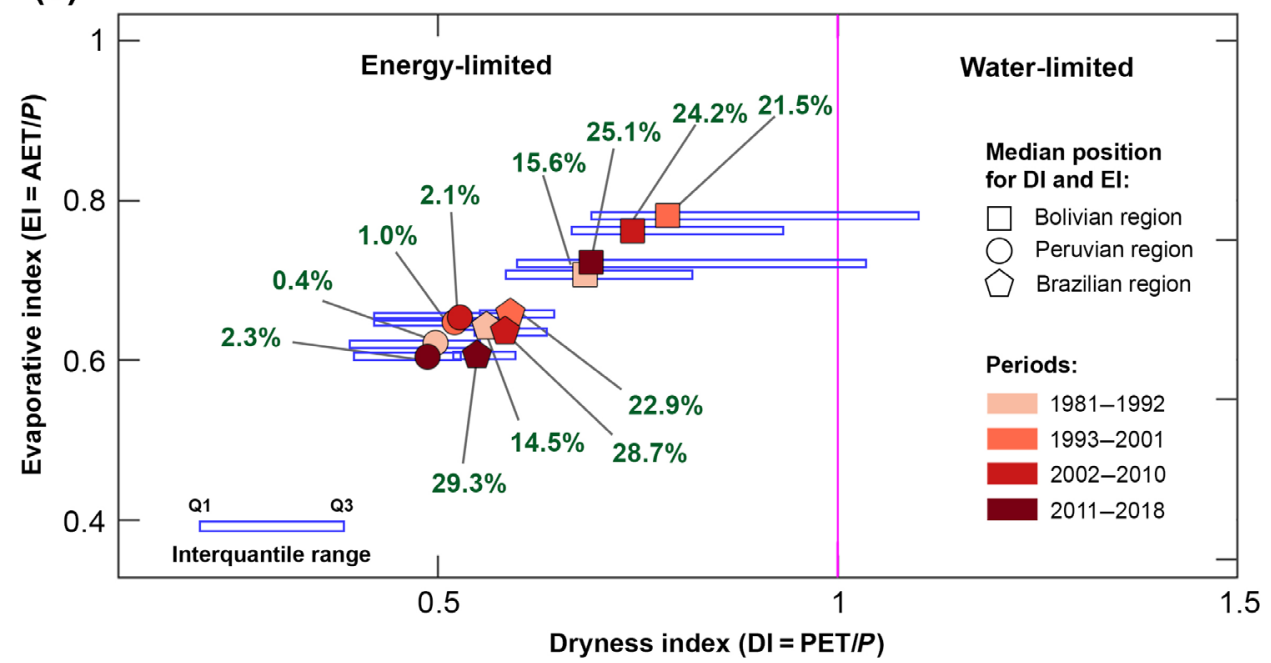

F I G URE 5 (a-d) Dryness versus evaporative index for the three regions and the four periods. The circle size is proportional to the value of the ratio of non-forest vegetation (RNF) averaged at the pixel scale over each of the four 10-year period. The probability distribution of the dryness index is shown for areas with less (greater) than $40 \%$ of RNF in green (red) as violin plots. The areas with a RNF above $40 \%$ as for 1992 are represented by red dots. (e) Distribution of the median values of DI and EI for each region (geometric shapes) and period (red scale colours); the corresponding percentage of non-forest vegetation value for each region and period is indicated in green. The interquartile range for DI is plotted as horizontal blue bars [Colour figure can be viewed at wileyonlinelibrary.com] 

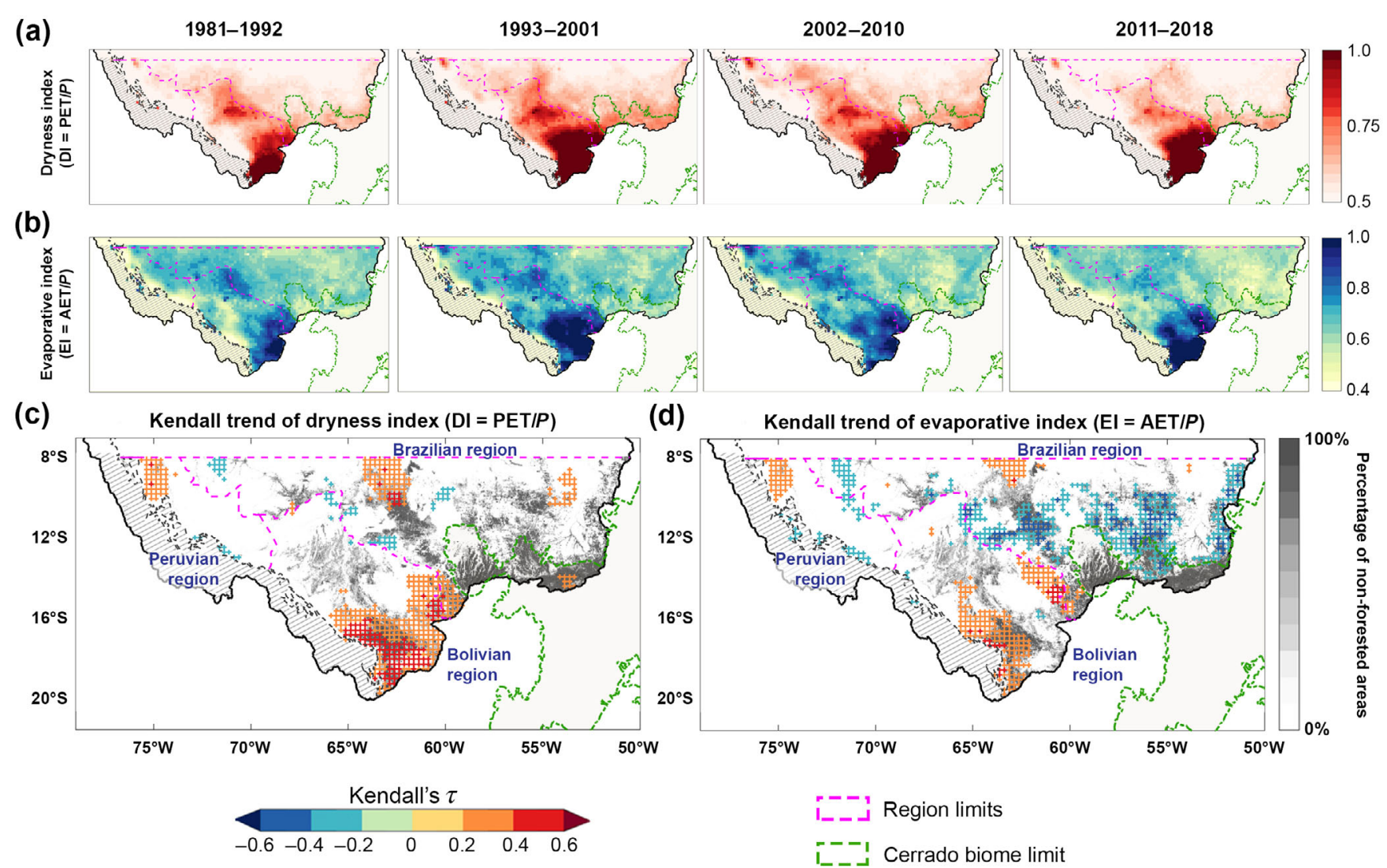

(d) Kendall trend of evaporative index $(E I=A E T / P)$

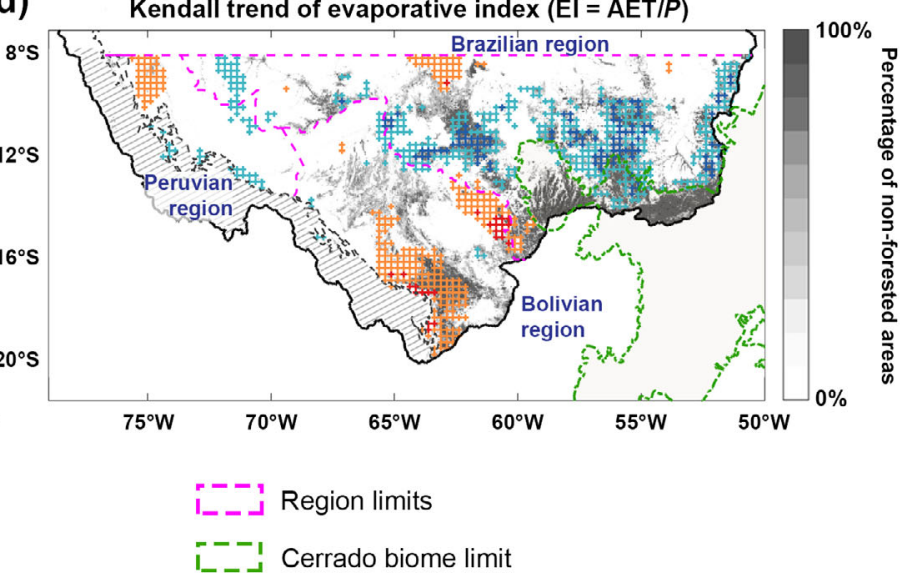

F I G U RE 6 Spatial distribution of the (a) dryness index (red range) and (b) evaporative index (green range) for the four decadal periods. Spatial distribution of the 1981-2018 Kendall coefficient $(\tau)$ of (c) dryness index and (d) evaporative index. Significant increase and decrease are indicated in red and blue, respectively. The grey scale background indicates the percentage of total non-forest vegetation areas as for 2018 [Colour figure can be viewed at wileyonlinelibrary.com]

increase could also be related to an increased sensible heat flux due to sub-regional changes in vegetation cover from forest to low-tree or crops. Considering the areas with low-RNF, the DI median value remains within the range $\sim 0.5$ to $\sim 1.0$ for all periods as can be observed from the frequency distribution plotted in green below the $x$ axis of Figure 5a-d, left column.

Over this region, the EI median shifted from 0.8-1.0 in the 1981-1992 period to 1.0-1.2 afterwards for highRNF areas; in fact, $\sim 22 \%$ of this region became EI values greater than 1.0 after 1992. This is clearly a consequence of a stronger decrease in $P$ than in AET, with AET being altered by forest loss and $P$ mainly by large-scale climate variability. In fact, previous studies have documented a rainfall diminution over the Bolivian Amazon related to an enhanced atmospheric subsidence over southern Amazonia, as a consequence of the intensification of the continental Hadley circulation (Arias et al., 2015; MolinaCarpio et al., 2017; Leite-Filho et al., 2019; Espinoza et al., 2019a; 2019b). Additionally, in low-RNF areas the EI median remained around 0.8-1.0 after 1992. Note that EI values may exceed 1.0 since a pixel-based Budyko-like approach is used, which does not guarantee a closed vertical water budget (see Section 2).

Figure 5e synthesizes on a single graph the distributions shown in Figures 5a-d, by plotting the median of DI and EI for each region and each period. For the Bolivian region, surface water and energy partitioning conditions indicate a trend to shift from energy-limited to water-limited conditions (vertical line in magenta) mainly for areas located in the southern Bolivian region during the analysed period (Figure 6). This could be interpreted as this hydro-climatic shift having created the conditions for a forest dieback in this region. It is also worth noting an apparent trend to return to energy-limited conditions for the last two periods (2002-2010 and 2011-2018), with great uncertainty however (DI equals to $0.74 \pm 0.3$ and $0.69 \pm 0.4$, respectively). Two factors may explain this somewhat uncertain and temporary trend to return to an energy-limited regime from 1993-2001 to the 2002-2010 and 2011-2018 periods: (a) PET decreased due to changes in surface temperature, humidity or wind speed; and (b) the increase in $P$ amount in northern Bolivian Amazon, mainly for the period 20022010 (Espinoza et al., 2019b). In fact, results suggest that 
$P$ variation plays a more important role, because despite the large interquartile intervals of DI, there is a general trend towards drying out mainly for areas in the southern areas (see Figure 6a,c) but with significant decadal fluctuations.

\subsection{2 | Peruvian and Brazilian regions}

For the Peruvian and Brazilian regions, the regime mainly remains energy-limited over the entire 1981-2018 period (Figure 5a-d, middle and right columns), except for a few areas in the Brazilian region. However, slightly higher values of the DI median are observed for high-RNF areas ( 0.65) compared to low-RNF areas $(\sim 0.6)$ in the Brazilian region. Besides, in the Peruvian region, there are only areas with RNF lower than $40 \%$ (low-RNF) and all of them remain in the energylimited region during all periods. The EI values for the Peruvian region show a higher dispersion than for the Brazilian region but with the median remaining around $\sim 0.7$ with a slight decline in the last period. Besides, over the high-RNF areas in the Brazilian region, EI also decreases slightly from $\sim 0.6$ to $\sim 0.5$ until the end of the period. This reflects the fact that, under relative stable rainfall conditions (Figure 3a), low-tree cover areas or crops (high-RNF) display a larger decrease in AET than forested areas (Figure 4c), inducing this slight decrease of EI.

In the Brazilian region, we observe (Figure 5e) that the greatest RNF increase is recorded from the first (1981-1992) to the second (1993-2001) period (14.5 to $22.9 \% \pm 0.5 \%$ ); however, the transition trend to waterlimited conditions occurs mainly the Bolivian region, which also has a large and similar increase in RNF for the same period ( 15.6 to $21.5 \% \pm 0.9 \%$ ), exemplifying the fact that the dependence of surface water and energy partitioning to RNF is controlled by both subregional and large-scale conditions.

In order to provide a spatial overview of the observed changes in the DI and the EI, we analysed the spatial distribution by the four decadal periods (Figure 6a,b) and the temporal trend for the total period (1981-2018) (Figure 6c,d). Evidence suggests that zones showing decreased precipitation tend towards a water-limited state. Most of the significant trends occur in zones that shows both scenarios, decreased precipitation and forest loss greater than $40 \%$, which are characterized by having crossed from an energy-limited to a water-limited behaviour over the study period, as it is observed in the Southern Bolivian region.

A significant increase in the trends of the DI and EI is also observed in the north-west of Peruvian region and in the north-central part in the Brazilian region. For the Peruvian region, this is mainly a consequence of a reduction in $P$, while for the Brazilian region it may be due to a greater decrease in $P$ than in AET (see Figures $3 \mathrm{~b}$ and $4 \mathrm{c}$ ). It is interesting to note that DI and EI (Figure 6c,d, respectively) have the same spatial trend pattern than $P$ (see Figure $3 \mathrm{a}$ ), which suggests that decrease in $P$ plays a major influence in the surface water and energy partitioning in Southern Amazonia.

\section{4 | DISCUSSIONS}

\section{1 | Potential factors related to land use changes and large-scale circulation}

Beyond the sole value of RNF evolution over decades, the different results obtained for the three regions are likely also related to their different proportion of forest converted into cropland versus low-tree cover, as shown in Figure S5. For instance, the changes in land cover from forest to low-tree cover (interpreted as the natural process of forest death), in relation with the total deforested areas, are significantly higher in the Bolivian region ( $28 \%)$ as compared to the Peruvian and Brazilian regions (3\% and $11 \%$, respectively). Among the factors that imply the loss of forest is the increase in fires, which are primarily a man-induced phenomenon (Cochrane, 2003). Additionally, this can also have an opposite meaning since according to Xu et al. (2020), the fraction of burned area increase in the Southern Amazon is also largely dependent on the ratio of forest loss. Fires can cause a rapid transition from tropical forest to savanna-like cover, however existing databases are much more recent than our analysis period (e.g., 2000's of MODIS with the Fire Information for Resource Management System database or the Global Fire Emissions Database) and therefore not fully relevant for this analysis.

Evidence suggests that decrease in $P$ in Southern Amazonia is also likely driven by large-scale processes related to a strengthening of the Walker and Hadley circulations. This strengthening enhances wind subsidence over the $10^{\circ} \mathrm{S}-20^{\circ} \mathrm{S}$ which suggests a reduction in deep convection and cloudiness (Arias et al., 2011; Espinoza et al., 2019a). Authors suggest that warm conditions in the north tropical Atlantic are associated with the enhanced wind subsidence over southern Amazonia and dry conditions over this region (Arias et al., 2020).

In addition to this, it is worth recalling that deforestation is also related to other variables influencing convective processes, such as vertical wind (see Supporting Information), which is statistically significantly correlated with RNF. Results indicate significant influence of land use 
(a)

Legend:
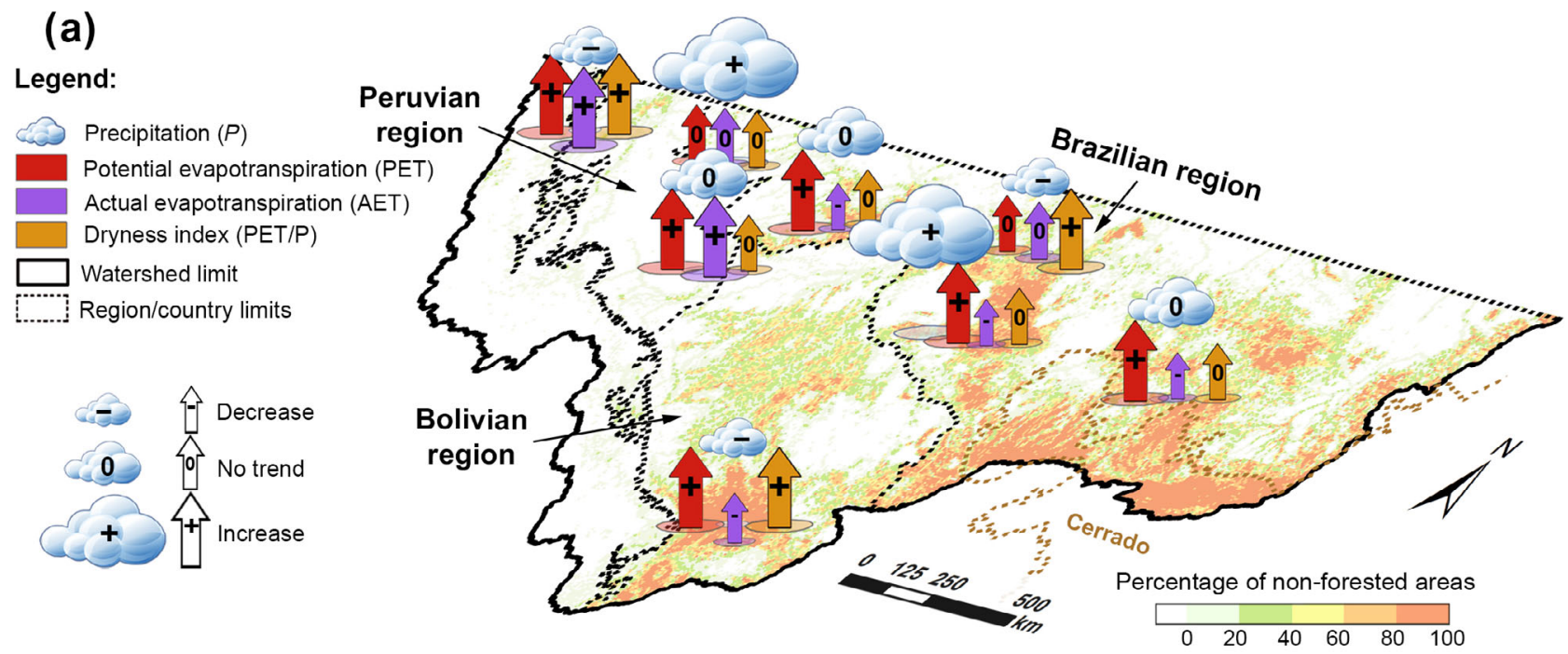

(b)

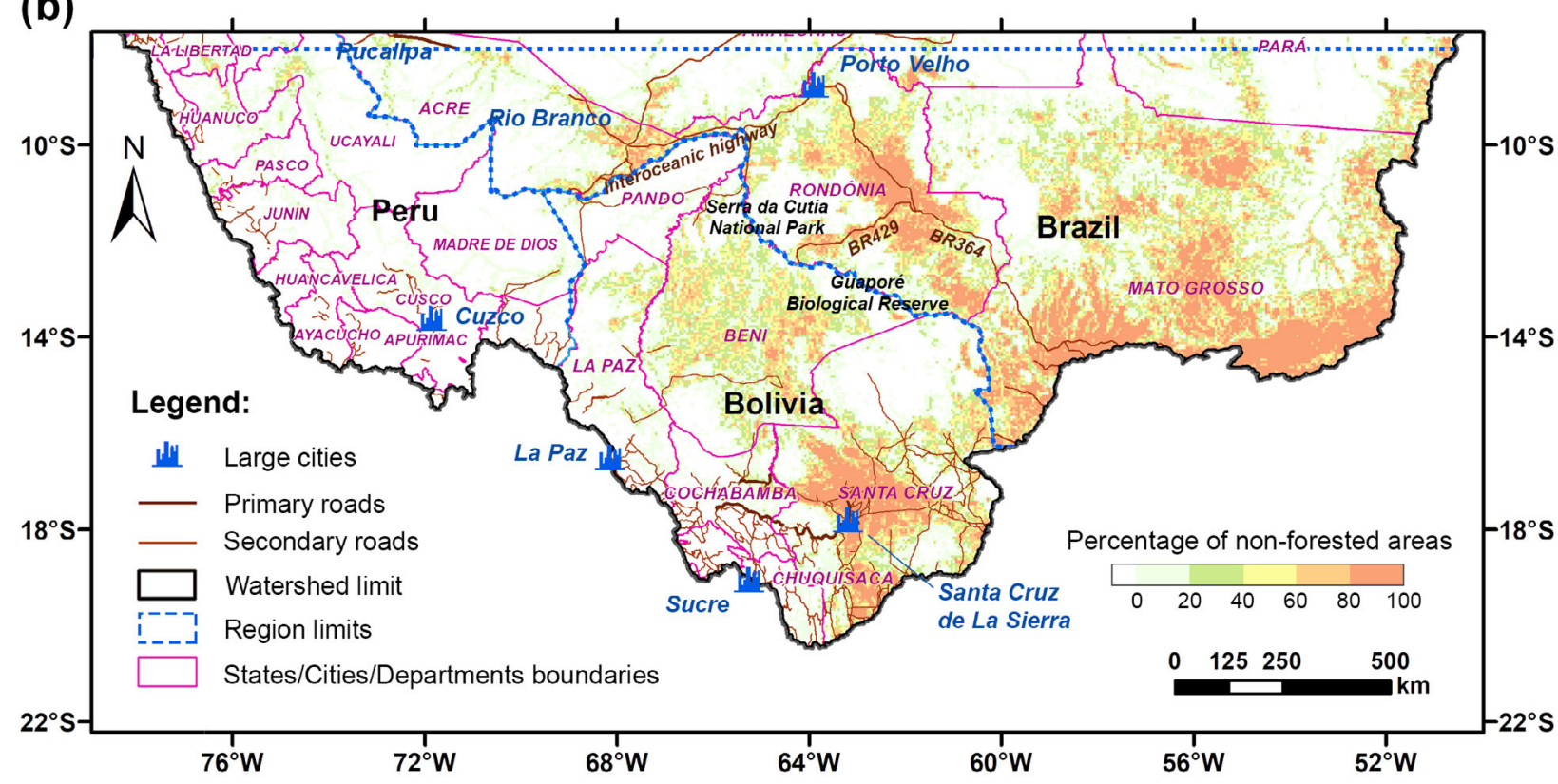

F I G URE 7 (a) Schematic distribution of increased (large icon with '+'), decreased (small icon with '-') and non-trend (medium icon with ' 0 ') for precipitation (cloud), potential evapotranspiration (red arrow), actual evapotranspiration (purple arrow) and dryness index (gold arrow), for areas displaying the most significant variations, over 1981-2018. The percentage of non-forest vegetation areas as for 2018 is represented by the green-red colour bar. (b) Map of political boundaries, roads, and main departments, cities and states for each region (Peruvian, Bolivian and Brazilian) [Colour figure can be viewed at wileyonlinelibrary.com]

change (from forest to low-tree cover) on vertical wind, since the Southern Bolivian region (south of $15^{\circ} \mathrm{S}$ where high-RNF are mainly placed) and the Brazilian regions have the highest rate of deforestation $(16.95 \% \pm 0.9 \%$ and $14.7 \% \pm 0.5 \%$, respectively) as compared to the Peruvian region $(1.7 \% \pm 0.5 \%)$ (Figure $\mathrm{S} 7$ ). This means that in areas with high-RNF, there is a significant decrease in vertical wind. In the Southern Amazon, convective processes are particularly active (Vera et al., 2006); therefore, a decrease in vertical wind could indicate a decrease in convective activity and rainfall. To gain a complete understanding of what is at play when relating the evolution of forest cover with rainfall changes, local processes should therefore be accounted for, through the use of tools such as numerical models (Eiras-Barca et al., 2020; RuizVásquez et al., 2020; Sierra et al., 2021). For instance, in a recent high-resolution modelling work, Sierra et al. (2021) found that a deforestation scenario of $45 \%$ of the Amazonian forest produce decrease in evapotranspiration and vertically integrated moisture convergence in central and southern Amazon, which also implies a reduction in the vertical velocity. These regional changes due to Amazon deforestation are associated with a rise in the atmospheric pressure at 
lower levels. This result suggests a complex interaction between changes in large-scale atmospheric circulation (e.g., Walker and Hadley circulations) and regional changes due to forest loss (Sierra et al., 2021).

In this study, we have identified spatially distributed linkages between hydro-climatic conditions and forest cover change in the Southern Amazon based on observations (semiological study). While the scope of this study was not to establish a cause-effect diagnosis of the complex physical interactions between climate and changes in vegetation cover, our observational analysis can be useful to complement modelling studies.

\section{2 | Geographical implications}

This section briefly synthesizes and classifies the detected hydro-climatic trends in a geographical perspective (for localization of regions and cities, see Figure 7b). We would like to highlight that this geographical perspective could be useful from a governance point of view for decision makers regarding future threats posed by changes in forest cover and associated changes in the main hydroclimatic variables.

A decrease in $P$ is observed in the Southern Bolivian Amazon, around Santa Cruz de La Sierra city (Bolivian region), as well as in small spots in the Peruvian Amazon (in Huánuco and Ucayali Regions, close to the Pucallpa city) in the Peruvian region and in the centre of the Rondônia State in the Brazilian region. Increase in $P$ occurs on the border between Peru and Brazil (Department of Ucayali and the Brazilian State of Acre, respectively) in the Peruvian region, but also, in the south of Rondônia state in the Brazilian region, where there is a 'tongue' of deforestation between the national park Serra da Cutia and the Guaporé Biological Reserve, along the BR429 and near to the BR364 highways (Figure $7 b$ ).

Increase in PET and decrease in AET mainly occurs in places with high forest loss such as around Santa Cruz de La Sierra city (Bolivian region). This is also witnessed in the Brazilian Arc of Deforestation (close to the border between the Brazilian Acre State and the Bolivian Pando Department), especially along the interoceanic highway and near Rio Branco city, the capital of the Acre State (east of the Peruvian region). The same applies to the Southern Rondônia and the Central Mato Grosso states (Brazilian region). Increase in PET and AET together only occur in most of the Peruvian Amazon (westernmost part of the Peruvian region), where the level of deforestation is still low compared to the Southern Brazilian and Bolivian Amazon. In areas where the $\sim 40-50 \%$ RNF threshold is exceeded, a significant decrease in $P$ and increase in AET are practically only observed in the Bolivian and Brazilian regions and according to our evidence, this threshold is still not exceeded in Peru.

Observed increase in the DI occurs in the same regions that are dominated by $P$ decreases, pointing out a hydroclimatic condition (water-limited) favourable to develop a low-tree cover, potentially threatening the maintenance of the remaining tropical forest. This occurs mostly in the Bolivian region (the Bolivian city of Santa Cruz de La Sierra being a hot spot in this respect), and in the north-westernmost parts of the Peruvian region (Ucayali Region in Peru) and Brazilian region (area of the Porto Velho city in the Northern Rondônia State in Brazil).

\section{5 | CONCLUSION AND FINAL REMARKS}

The relationships existing at sub-regional scales between forest loss and the evolution of water and energy partitioning in the Southern Amazon basin vary largely depending on the location considered (e.g., Southern Amazon forest as a whole, Southern Bolivian Amazon, Southwestern Amazon or just the Arc of Deforestation zone), as a result of different dynamics in climate and land use changes. Most important is the fact that the decrease in precipitation induced either by large-scale climate modifications or by changing local conditions may lead to a transition from energy- to water-limited conditions, in case of high deforestation ratios (e.g., above $\sim 40 \%$ ). This situation is only observed in the Southern Bolivian Amazon at the moment, which highlights the necessity of working at local scales if one is to apprehend the conditions driving to a forest dieback.

In many areas of large forest loss, such as the Southern Bolivian and Brazilian Amazon, a growing imbalance is observed between increasing potential and decreasing AET, showing that extensively forested lands are crucial to prevent critical changes in the sub-regional water and energy partitioning. The central Peruvian Amazon is a particular case where the forest loss is not high while a decrease in precipitation affects the water balance, but without any obvious land cover transition. Additionally, the land use transition from forest to a low-tree cover is already three times higher in percentage for the Southern Bolivian region than for the Peruvian and Brazilian regions. This makes this region prone to large-scale shifts especially if areas that are not still highly deforested become water-limited due to changing climate conditions.

Recent studies show that hydro-climate changes in tropic regions are globally related to modifications of the large-scale atmospheric circulation associated with 
anthropogenic global warming. Coherent with this, it is noticeable that changes in the regional Hadley circulation over tropical South America have been related to a rainfall diminution in Southern Amazon and an increased dryseason length. Thus, large-scale climate changes may combine with regional vegetation changes to produce a positive feedback leading to an increased forest loss (e.g., in Southern Bolivian Amazon). This picture is somewhat different from the one observed in the Southern Brazilian Amazon, where deforestation is occurring at a high rate, due to anthropogenic changes (cultivation of formerly forested areas), but where no systematic change in rainfall is observed.

We would like to point out that the methodology presented in this research can be used in any region of the Amazon or in any part of the world, since the information we used has a global coverage. However, due to the sub-regional scale of our analyses and due to the different conditions and results of interactions between land use change and hydro-climatic variables shown in this research, our conclusions cannot be extrapolated to other regions of the Amazon basin (i.e., north of $8^{\circ} \mathrm{S}$ ) that have not been the object of this study.

\section{ACKNOWLEDGEMENTS}

This research has been supported by the French AMANECER-MOPGA project funded by ANR and IRD (ref. ANR-18-MPGA-0008). Paola A. Arias has been supported by MINCIENCIAS through the Grant 80740-490-220. We wish to thank the following agencies/ organizations for providing access to data: The Climate Hazards Group Infrared Precipitation for providing CHIRPS data (information available at http://chg.geog. ucsb.edu/data/chirps/), Ghent University for providing GLEAM data (https://www.gleam.eu/), the eartH2Observe outputs (https://earth2observe.github.io/water-resourcereanalysis-v1/), the European Space Agency (ESA) Climate Change Initiative (CCI) and the Copernicus Climate Change Service (C3S) for providing the Global Land Cover maps (https://maps.elie.ucl.ac.be/CCI/viewer/).

\section{CONFLICT OF INTEREST}

The authors declare no conflicts of interest.

\section{AUTHOR CONTRIBUTIONS}

Sly Wongchuig: Conceptualization; formal analysis; data curation; visualization; methodology; writing review and editing. Jhan Carlo Espinoza: Conceptualization; formal analysis; funding acquisition; methodology; writing - review and editing. Thomas Condom: Conceptualization; formal analysis; methodology; writing - review and editing. Hans Segura: Writing - review and editing. Josyane Ronchail: Formal analysis; writing
- review and editing. Paola Arias: Formal analysis; writing - review and editing. Clementine Junquas: Writing - review and editing. Antoine Rabatel: Formal analysis; writing - review and editing. Thierry Lebel: Formal analysis; investigation; supervision; writing - review and editing.

\section{DATA AVAILABILITY STATEMENT}

The data that support the findings of this study are available upon reasonable request from the authors.

\section{ORCID}

Sly Wongchuig (1) https://orcid.org/0000-0002-1116-0742

Jhan Carlo Espinoza (10 https://orcid.org/0000-0001-77328504

Thomas Condom (10) https://orcid.org/0000-0002-44088580

Hans Segura (i) https://orcid.org/0000-0002-6720-5882 Josyane Ronchail (i) https://orcid.org/0000-0002-88246771

Paola A. Arias (10) https://orcid.org/0000-0003-1726-6000 Clementine Junquas (D) https://orcid.org/0000-0003-15425602

Antoine Rabatel (1) https://orcid.org/0000-0002-5304-1055 Thierry Lebel (10) https://orcid.org/0000-0002-1297-6751

\section{REFERENCES}

Agudelo, J., Arias, P.A., Vieira, S.C. and Martínez, J.A. (2019) Influence of longer dry seasons in the Southern Amazon on patterns of water vapor transport over northern South America and the Caribbean. Climate Dynamics, 52(5-6), 2647-2665. https://doi. org/10.1007/s00382-018-4285-1.

Alkama, R. and Cescatti, A. (2016) Biophysical climate impacts of recent changes in global forest cover. Science, 351(6273), 600604. https://doi.org/10.1126/science.aac8083.

Alves, L.M., Marengo, J.A., Fu, R. and Bombardi, R.J. (2017) Sensitivity of Amazon regional climate to deforestation. American Journal of Climate Change, 6(1), 75-98. https://doi.org/10.4236/ ajcc.2017.61005.

Aragão, L.E.O.C., Anderson, L.O., Fonseca, M.G., Rosan, T.M., Vedovato, L.B., Wagner, F.H., Silva, C.V.J., Silva Junior, C.H.L., Arai, E., Aguiar, A.P., Barlow, J., Berenguer, E., Deeter, M.N., Domingues, L.G., Gatti, L., Gloor, M., Malhi, Y., Marengo, J.A., Miller, J.B., Phillips, O.L. and Saatchi, S. (2018) 21st Century drought-related fires counteract the decline of Amazon deforestation carbon emissions. Nature Communications, 9(1), 1-12. https://doi.org/10.1038/s41467-017-02771-y.

Aragão, L.E.O.C., Malhi, Y., Barbier, N., Lima, A., Shimabukuro, Y., Anderson, L. and Saatchi, S. (2008) Interactions between rainfall, deforestation and fires during recent years in the Brazilian Amazonia. Philosophical Transactions of the Royal Society B: Biological Sciences, 363(1498), 1779-1785. https://doi.org/10.1098/rstb.2007.0026.

Arantes, A.E., Ferreira, L.G. and Coe, M.T. (2016) The seasonal carbon and water balances of the Cerrado environment of Brazil: past, present, and future influences of land cover and land use. 
ISPRS Journal of Photogrammetry and Remote Sensing, 117, 6678. https://doi.org/10.1016/j.isprsjprs.2016.02.008.

Arias, P.A., Fu, R., Hoyos, C.D., Li, W. and Zhou, L. (2011) Changes in cloudiness over the Amazon rainforests during the last two decades: diagnostic and potential causes. Climate Dynamics, 37(5), 1151-1164. https://doi.org/10.1007/s00382-010-0903-2.

Arias, P.A., Fu, R., Vera, C. and Rojas, M. (2015) A correlated shortening of the North and South American monsoon seasons in the past few decades. Climate Dynamics, 45(11-12), 3183-3203. https://doi.org/10.1007/s00382-015-2533-1.

Arias, P.A., Martinez, A., Mejía, J.D., Pazos, M.J., Espinoza, J.C. and Wongchuig, S.C. (2020) Changes in normalized difference vegetation index in the Orinoco and Amazon river basins: Links to tropical atlantic surface temperatures. Journal of Climate, 33(19), 8537-8559. https://doi.org/10.1175/JCLI-D-19-0696.1.

Baker, J.C.A. and Spracklen, D.V. (2019) Climate benefits of intact Amazon forests and the biophysical consequences of disturbance. Frontiers in Forests and Global Change, 2, 1-13. https:// doi.org/10.3389/ffgc.2019.00047.

Barichivich, J., Gloor, E., Peylin, P., Brienen, R.J.W., Schöngart, J., Espinoza, J.C. and Pattnayak, K.C. (2018) Recent intensification of Amazon flooding extremes driven by strengthened Walker circulation. Science Advances, 4(9), eaat8785. https:// doi.org/10.1126/sciadv.aat8785.

Bathiany, S., Claussen, M., Brovkin, V., Raddatz, T. and Gayler, V. (2010) Combined biogeophysical and biogeochemical effects of large-scale forest cover changes in the MPI earth system model. Biogeosciences, 7(5), 1383-1399. https://doi.org/10.5194/bg-7-13832010.

Beck, H.E., Vergopolan, N., Pan, M., Levizzani, V., van Dijk, A.I.J. M., Weedon, G.P., Brocca, L., Pappenberger, F., Huffman, G.J. and Wood, E.F. (2017) Global-scale evaluation of 22 precipitation datasets using gauge observations and hydrological modeling. Hydrology and Earth System Sciences, 21(12), 6201-6217. https://doi.org/10.5194/hess-21-6201-2017.

Brando, P.M., Balch, J.K., Nepstad, D.C., Morton, D.C., Putz, F.E., Coe, M.T., Silvério, D., Macedo, M.N., Davidson, E.A., Nóbrega, C.C., Alencar, A. and Soares-Filho, B.S. (2014) Abrupt increases in Amazonian tree mortality due to drought-fire interactions. Proceedings of the National Academy of Sciences of the United States of America, 111(17), 6347-6352. https://doi. org/10.1073/pnas.1305499111.

Brando, P.M., Soares-Filho, B., Rodrigues, L., Assunção, A., Morton, D., Tuchschneider, D., Fernandes, E.C.M., Macedo, M. N., Oliveira, U. and Coe, M.T. (2020) The gathering firestorm in southern Amazonia. Science Advances, 6(2), 1-10. https:// doi.org/10.1126/sciadv.aay1632.

Carvalho Oliveira, J., Aguiar, W., Cirano, M., Genz, F. and de Amorim, F.N. (2018) A climatology of the annual cycle of river discharges into the Brazilian continental shelves: from seasonal to interannual variability. Environmental Earth Sciences, 77(5), 1-17. https://doi.org/10.1007/s12665-018-7349-y.

Casagrande, E., Recanati, F. and Melià, P. (2018) Assessing the influence of vegetation on the water budget of tropical areas. IFAC-PapersOnLine, 51(5), 1-6. https://doi.org/10.1016/j.ifacol. 2018.06.190.

Chavez, S.P. and Takahashi, K. (2017) Orographic rainfall hot spots in the Andes-Amazon transition according to the TRMM precipitation radar and in situ data. Journal of Geophysical Research: Atmospheres, 122(11), 5870-5882. https://doi.org/10. 1002/2016JD026282.
Cochrane, M.A. (2003) Fire science for rainforests. Nature, 421(6926), 913-919. https://doi.org/10.1038/nature01437.

Costa, M.H. and Pires, G.F. (2010) Effects of Amazon and Central Brazil deforestation scenarios on the duration of the dry season in the arc of deforestation. International Journal of Climatology, 30(13), 1970-1979. https://doi.org/10.1002/joc.2048.

Culf, A.D., Esteves, J.L., Marques Filho, A.d.O and da Rocha, H.R. (1996) Radiation, temperature and humidity over forest and pasture in Amazonia. In: J.H.C. Gash, (Ed.), Amazonian deforestation and climate (pp. 175-191). New York, NY: John Wiley.

Cysneiros, V.C., Dalmaso, C.A., Pelissari, A.L., de Mattos, P.P., de Souza, L. and Machado, S.D.A. (2018) Spatial patterns and interactions of dominant tree species in an Amazon tropical forest. Revista de Biología Tropical, 66(3), 1009. https://doi.org/ 10.15517/rbt.v66i3.31216.

da Motta Paca, V.H., Espinoza-Dávalos, G.E., Hessels, T.M., Moreira, D.M., Comair, G.F. and Bastiaanssen, W.G.M. (2019) The spatial variability of actual evapotranspiration across the Amazon River Basin based on remote sensing products validated with flux towers. Ecological Processes, 8(1), 1-20. https:// doi.org/10.1186/s13717-019-0158-8.

Damien, A., Isabelle, T., Christovam, B., Nicolas, J. and Vincent, D. (2017) Land use sustainability on the South-Eastern Amazon agricultural frontier: recent progress and the challenges ahead. Applied Geography, 80, 86-97. https://doi.org/10.1016/j.apgeog. 2017.02.003.

Davidson, E.A., De Araüjo, A.C., Artaxo, P., Balch, J.K., Brown, I. F., Mercedes, M.M., Coe, M.T., Defries, R.S., Keller, M., Longo, M., Munger, J.W., Schroeder, W., Soares-Filho, B.S., Souza, C.M. and Wofsy, S.C. (2012) The Amazon basin in transition. Nature, 481(7381), 321-328. https://doi.org/10.1038/ nature10717.

Debortoli, N.S., Dubreuil, V., Funatsu, B., Delahaye, F., de Oliveira, C.H., Rodrigues-Filho, S., Saito, C.H. and Fetter, R. (2015) Rainfall patterns in the Southern Amazon: a chronological perspective (1971-2010). Climatic Change, 132(2), 251-264. https://doi.org/10.1007/s10584-015-1415-1.

Debortoli, N.S., Dubreuil, V., Hirota, M., Filho, S.R., Lindoso, D.P. and Nabucet, J. (2017) Detecting deforestation impacts in Southern Amazonia rainfall using rain gauges. International Journal of Climatology, 37(6), 2889-2900. https://doi.org/10. 1002/joc. 4886 .

Dias, L.C.P., Pimenta, F.M., Santos, A.B., Costa, M.H. and Ladle, R. J. (2016) Patterns of land use, extensification, and intensification of Brazilian agriculture. Global Change Biology, 22(8), 2887-2903. https://doi.org/10.1111/gcb.13314.

Eiras-Barca, J., Dominguez, F., Yang, Z., Chug, D., Nieto, R., Gimeno, L. and Miguez-Macho, G. (2020) Changes in South American hydroclimate under projected Amazonian deforestation. Annals of the New York Academy of Sciences, 1472(1), 104122. https://doi.org/10.1111/nyas.14364.

ESA (2017) Land Cover CCI Product User Guide Version 2 (No. 2; p. 105). European Space Agency. https://maps.elie.ucl.ac.be/ CCI/viewer/download/ESACCI-LC-Ph2-PUGv2_2.0.pdf. Accessed 17th September 2020.

Espinoza, J.C., Chavez, S., Ronchail, J., Junquas, C., Takahashi, K. and Lavado, W. (2015) Rainfall hotspots over the southern tropical Andes: spatial distribution, rainfall intensity, and relations with large-scale atmospheric circulation. Water Resources Research, 51(5), 3459-3475. https://doi.org/10.1002/2014WR01 6273. 
Espinoza, J.C., Ronchail, J., Frappart, F., Lavado, W., Santini, W. and Guyot, J.L. (2013) The major floods in the Amazonas River and tributaries (Western Amazon Basin) during the 1970-2012 period: a focus on the 2012 flood. Journal of Hydrometeorology, 14(3), 1000-1008. https://doi.org/10.1175/JHM-D-12-0100.1.

Espinoza, J.C., Ronchail, J., Guyot, J.L., Cochonneau, G., Naziano, F., Lavado, W., De Oliveira, E., Pombosa, R. and Vauchel, P. (2009a) Spatio-temporal rainfall variability in the Amazon basin countries (Brazil, Peru, Bolivia, Colombia, and Ecuador). International Journal of Climatology, 29(11), 15741594. https://doi.org/10.1002/joc.1791.

Espinoza, J.C., Guyot, J.L., Ronchail, J., Cochonneau, G., Filizola, N., Fraizy, P., Labat, D., De Oliveira, E., Ordoñez, J.J. \& Vauchel, P. (2009b) Contrasting regional discharge evolutions in the Amazon basin (1974-2004). Journal of Hydrology, 375(3-4), 297-311. https://doi.org/10.1016/j.jhydrol.2009.03.004.

Espinoza, J.C., Ronchail, J., Marengo, J.A. and Segura, H. (2019a) Contrasting north-south changes in Amazon wet-day and dryday frequency and related atmospheric features (1981-2017). Climate Dynamics, 52(9-10), 5413-5430. https://doi.org/10. 1007/s00382-018-4462-2.

Espinoza, J.C., Segura, H., Ronchail, J., Drapeau, G. and GutierrezCori, O. (2016) Evolution of wet-day and dry-day frequency in the western Amazon basin: relationship with atmospheric circulation and impacts on vegetation. Water Resources Research, 52(11), 8546-8560. https://doi.org/10.1002/2016WR019305.

Espinoza, J.C., Sörensson, A.A., Ronchail, J., Molina-Carpio, J., Segura, H., Gutierrez-Cori, O., Ruscica, R., Condom, T. and Wongchuig-Correa, S. (2019b) Regional hydro-climatic changes in the Southern Amazon Basin (Upper Madeira Basin) during the 1982-2017 period. Journal of Hydrology: Regional Studies, 26, 100637. https://doi.org/10.1016/j.ejrh.2019.100637.

Eva, H.D., Huber, O., Achard, F., Balslev, H., Beck, S., Behling, H., Belward, A.S., Beuchle, R., Cleef, A.M., Colchester, M., Duivenvoorden, J., Hoogmoed, M., Junk, W., Kabat, P., Kruijt, B., Malhi, Y., Müller, J.M., Pereira, J.M., Peres, C., Prance, G.T., Roberts, J. and Salo, J. (2005) A proposal for defining the geographical boundaries of Amazonia; synthesis of the results from an expert consultation workshop organized by the European Commission in collaboration with the Amazon Cooperation Treaty Organization - JRC Ispra, 7-8 June 2005.

Fassoni-Andrade, A.C., Fleischmann, A.S., Papa, F., de Paiva, R.C.D., Wongchuig, S., Melack, J.M., Moreira, A.A., Paris, A., Ruhoff, A., Barbosa, C., Faria, C., Maciel, D.A., de Moraes Novo, E.M.L., Durand, F., Frappart, F., Aires, F., Abrahão, G.M., Ferreira-Ferreira, J., Espinoza, J.C., Laipelt, L., Costa, M.H., Espinoza-Villar, R., Calmant, S. and Pellet, V. (2021) Amazon hydrology from space: scientific advances and future challenges. Reviews of Geophysics, 69, 1-97. https://doi.org/10. 1029/2020RG000728.

Figueroa, S.N. and Nobre, C.A. (1990) Precipitation distribution over central and western tropical South America. Climanálise, 6, 36-40.

Fisch, G., Tota, J., Machado, L.A.T., Silva Dias, M.A.F., Lyra, R.F.D. F., Nobre, C.A., Dolman, A.J. and Gash, J.H.C. (2004) The convective boundary layer over pasture and forest in Amazonia. Theoretical and Applied Climatology, 78(1-3), 47-59. https:// doi.org/10.1007/s00704-004-0043-x.

Fu, R., Yin, L., Li, W., Arias, P.A., Dickinson, R.E., Huang, L., Chakraborty, S., Fernandes, K., Liebmann, B., Fisher, R. and Myneni, R.B. (2013) Increased dry-season length over southern Amazonia in recent decades and its implication for future climate projection. Proceedings of the National Academy of Sciences of the United States of America, 110(45), 18110-18115. https://doi.org/10.1073/pnas.1302584110.

Funk, C., Peterson, P., Landsfeld, M., Pedreros, D., Verdin, J., Shukla, S., Husak, G., Rowland, J., Harrison, L., Hoell, A. and Michaelsen, J. (2015) The climate hazards infrared precipitation with stations - a new environmental record for monitoring extremes. Scientific Data, 2, 1-21. https://doi.org/10.1038/sdata. 2015.66.

García-García, D. and Ummenhofer, C.C. (2015) Multidecadal variability of the continental precipitation annual amplitude driven by AMO and ENSO. Geophysical Research Letters, 42(2), 526535. https://doi.org/10.1002/2014GL062451.

Gash, J.H.C. and Nobre, C.A. (1997) Climatic effects of Amazonian deforestation: some results from ABRACOS. Bulletin of the American Meteorological Society, 78(5), 823-830. https://doi. org/10.1175/1520-0477(1997)078<0823:CEOADS>2.0.CO;2.

Gutierrez-Cori, O., Espinoza, J.C., Li, L.Z.X., Wongchuig, S., Arias, P.A., Ronchail, J. and Segura, H. (2021) On the hydroclimate-vegetation relationship in the southwestern Amazon during the 2000-2019 period. Frontiers in Water, 3, 1-20. https://doi.org/10.3389/frwa.2021.648499.

Haghtalab, N., Moore, N., Heerspink, B.P. and Hyndman, D.W. (2020) Evaluating spatial patterns in precipitation trends across the Amazon basin driven by land cover and global scale forcings. Theoretical and Applied Climatology, 140, 411-427. https://doi.org/10.1007/s00704-019-03085-3.

Hansen, M.C., Potapov, P.V., Moore, R., Hancher, M., Turubanova, S. A., Tyukavina, A., Thau, D., Stehman, S.V., Goetz, S.J., Loveland, T.R., Kommareddy, A., Egorov, A., Chini, L., Justice, C. O. and Townshend, J.R.G. (2013) High-resolution global maps of 21st-century forest cover change. Science, 342(6160), 850-853. https://doi.org/10.1126/science.1244693.

Hirota, M., Holmgren, M., Van Nes, E.H. and Scheffer, M. (2011) Global resilience of tropical forest and savanna to critical transitions. Science, 334(6053), 232-235. https://doi.org/10.1126/science.1210657.

Kendall, M.G. (1975) Rank Correlation Methods. London: Charles Griffin.

Khanna, J., Medvigy, D., Fueglistaler, S. and Walko, R. (2017) Regional dry-season climate changes due to three decades of Amazonian deforestation. Nature Climate Change, 7(3), 200204. https://doi.org/10.1038/nclimate3226.

Killeen, T.J., Douglas, M., Consiglio, T., Jørgensen, P.M. and Mejia, J. (2007) Dry spots and wet spots in the Andean hotspot. Journal of Biogeography, 34(8), 1357-1373. https://doi.org/10. 1111/j.1365-2699.2006.01682.x.

Kim, Y., Knox, R.G., Longo, M., Medvigy, D., Hutyra, L.R., Pyle, E. H., Wofsy, S.C., Bras, R.L. and Moorcroft, P.R. (2012) Seasonal carbon dynamics and water fluxes in an Amazon rainforest. Global Change Biology, 18(4), 1322-1334. https://doi.org/10. 1111/j.1365-2486.2011.02629.x.

Lamarche, C., Santoro, M., Bontemps, S., d'Andrimont, R., Radoux, J., Giustarini, L., Brockmann, C., Wevers, J., Defourny, P. and Arino, O. (2017) Compilation and validation of sar and optical data products for a complete and global map of inland/ocean water tailored to the climate modeling community. Remote Sensing, 9(1), 1-20. https://doi.org/10.3390/rs9010036.

Lavado Casimiro, W.S., Labat, D., Ronchail, J., Espinoza, J.C. and Guyot, J.L. (2013) Trends in rainfall and temperature in the Peruvian Amazon-Andes basin over the last 40years (1965-2007). Hydrological Processes, 27, 2944-2957. 
Lawrence, D. and Vandecar, K. (2015) Effects of tropical deforestation on climate and agriculture. Nature Climate Change, 5(1), 27-36. https://doi.org/10.1038/nclimate2430.

Le Page, Y., Morton, D., Hartin, C., Bond-Lamberty, B., Pereira, J. M.C., Hurtt, G. and Asrar, G. (2017) Synergy between land use and climate change increases future fire risk in Amazon forests. Earth System Dynamics, 8(4), 1237-1246. https://doi.org/10. 5194/esd-8-1237-2017.

Lee, J.-E., Oliveira, R.S., Dawson, T.E. and Fung, I. (2005) Root functioning modifies seasonal climate. Proceedings of the National Academy of Sciences of the United States of America, 102(49), 17576-17581. https://doi.org/10.1073/pnas.0508785102.

Leite-Filho, A.T., de Sousa Pontes, V.Y. and Costa, M.H. (2019) Effects of deforestation on the onset of the rainy season and the duration of dry spells in southern Amazonia. Journal of Geophysical Research: Atmospheres, 124(10), 5268-5281. https://doi. org/10.1029/2018JD029537.

Leite-Filho, A.T., Soares-Filho, B.S., Davis, J.L., Abrahão, G.M. and Börner, J. (2021) Deforestation reduces rainfall and agricultural revenues in the Brazilian Amazon. Nature Communications, 12(1), 2591. https://doi.org/10.1038/s41467-021-22840-7.

Lenton, T.M., Held, H., Kriegler, E., Hall, J.W., Lucht, W., Rahmstorf, S. and Schellnhuber, H.J. (2008) Tipping elements in the Earth's climate system. Proceedings of the National Academy of Sciences of the United States of America, 105(6), 17861793. https://doi.org/10.1073/pnas.0705414105.

Liang, Y.-C., Lo, M.-H., Lan, C.-W., Seo, H., Ummenhofer, C.C., Yeager, S., Wu, R.-J. and Steffen, J.D. (2020) Amplified seasonal cycle in hydroclimate over the Amazon river basin and its plume region. Nature Communications, 11(1), 4390. https://doi. org/10.1038/s41467-020-18187-0.

Liu, Y.Y., Dorigo, W.A., Parinussa, R.M., de Jeu, R.A.M., Wagner, W., McCabe, M.F., Evans, J.P. and van Dijk, A.I.J.M. (2012) Trend-preserving blending of passive and active microwave soil moisture retrievals. Remote Sensing of Environment, 123, 280-297. https://doi.org/10.1016/j.rse.2012.03.014.

Liu, Y.Y., van Dijk, A.I.J.M., McCabe, M.F., Evans, J.P. and de Jeu, R.A.M. (2013) Global vegetation biomass change (1988-2008) and attribution to environmental and human drivers. Global Ecology and Biogeography, 22(6), 692-705. https://doi.org/10.1111/geb.12024.

Lovejoy, T.E. and Nobre, C. (2018) Amazon tipping point. Science Advances, 4(2), 1-2. https://doi.org/10.1126/sciadv.aat2340.

Marengo, J.A. (1995) Interannual variability of deep convection over the tropical South American sector as deduced from ISCCP C2 data. International Journal of Climatology, 15(9), 995-1010. https://doi.org/10.1002/joc.3370150906.

Marengo, J.A. (2004) Interdecadal variability and trends of rainfall across the Amazon basin. Theoretical and Applied Climatology, 78(1-3), 79-96. https://doi.org/10.1007/s00704-004-0045-8.

Marengo, J.A., Tomasella, J., Alves, L.M., Soares, W.R. and Rodriguez, D.A. (2011) The drought of 2010 in the context of historical droughts in the Amazon region. Geophysical Research Letters, 38(12), 1-5. https://doi.org/10.1029/2011GL047436.

Martens, B., Miralles, D.G., Lievens, H., van der Schalie, R., de Jeu, R. A.M., Fernández-Prieto, D., Beck, H.E., Dorigo, W.A. and Verhoest, N.E.C. (2017) GLEAM v3: satellite-based land evaporation and root-zone soil moisture. Geoscientific Model Development, 10(5), 1903-1925. https://doi.org/10.5194/gmd-10-1903-2017.

Molina-Carpio, J., Espinoza, J.C., Vauchel, P., Ronchail, J., Gutierrez Caloir, B., Guyot, J.L. and Noriega, L. (2017)
Hydroclimatology of the Upper Madeira River basin: spatiotemporal variability and trends. Hydrological Sciences Journal, 62(6), 911-927. https://doi.org/10.1080/02626667.2016.1267861.

Moreira, A.A., Ruhoff, A.L., Roberti, D.R., de Arruda Souza, V., da Rocha, H.R. and de Paiva, R.C.D. (2019) Assessment of terrestrial water balance using remote sensing data in South America. Journal of Hydrology, 575, 131-147. https://doi.org/10.1016/ j.jhydrol.2019.05.021.

Nepstad, D.C., de Carvalho, C.R., Davidson, E.A., Jipp, P.H., Lefebvre, P.A., Negreiros, G.H., da Silva, E.D., Stone, T.A., Trumbore, S.E. and Vieira, S. (1994) The role of deep roots in the hydrological and carbon cycles of Amazonian forests and pastures. Nature, 372, 666-669.

Nobre, C.A. and Borma, L.D.S. (2009) "Tipping points" for the Amazon forest. Current Opinion in Environmental Sustainability, 1(1), 28-36. https://doi.org/10.1016/j.cosust.2009.07.003.

Nobre, C.A., Sampaio, G., Borma, L.S., Castilla-Rubio, J.C., Silva, J. S. and Cardoso, M. (2016) Land-use and climate change risks in the amazon and the need of a novel sustainable development paradigm. Proceedings of the National Academy of Sciences of the United States of America, 113(39), 10759-10768. https://doi. org/10.1073/pnas.1605516113.

Nobre, C.A., Sellers, P.J. and Shukla, J. (1991) Amazonian deforestation and regional climate change. Journal of Climate, 4, 957-988.

Pan, S., Pan, N., Tian, H., Friedlingstein, P., Sitch, S., Shi, H., Arora, V.K., Haverd, V., Jain, A.K., Kato, E., Lienert, S., Lombardozzi, D., Nabel, J.E.M.S., Ottle, C., Poulter, B. \& Zaehle, S. (2020) Evaluation of global terrestrial evapotranspiration using stateof-the-art approaches in remote sensing, machine learning and land surface modeling. Hydrology and Earth System Sciences, 24 (3), 1485-1509. https://doi.org/10.5194/hess-24-1485-2020.

Pires, M.O. (2020) 'Cerrado', old and new agricultural frontiers. Brazilian Political Science Review, 14(3), 1-24. https://doi.org/ 10.1590/1981-3821202000030006.

Prevedello, J.A., Winck, G.R., Weber, M.M., Nichols, E. and Sinervo, B. (2019) Impacts of forestation and deforestation on local temperature across the globe. PLoS One, 14(3), 1-18. https://doi.org/10.1371/journal.pone.0213368.

Ratter, J.A., Ribeiro, J.F. and Bridgewater, S. (1997) The Brazilian cerrado vegetation and threats to its biodiversity. Annals of Botany, 80(3), 223-230. https://doi.org/10.1006/ anbo.1997.0469.

Reis, T., Russo, G., Ribeiro, V., Moutinho, P., Guimarães, A., Stabile, M., Alencar, A., Crisostomo, A.C., Silva, D., Shimbo, J. and IPAM. (2017) Climate challenges and opportunities in the Brazilian cerrado. Policy brief. Belém do Pará: IPAM, p. 3.

Rodell, M., Houser, P.R., Jambor, U., Gottschalck, J., Mitchell, K., Meng, C.J., Arsenault, K., Cosgrove, B., Radakovich, J., Bosilovich, M., Entin, J.K., Walker, J.P., Lohmann, D. and Toll, D. (2004) The global land data assimilation system. Bulletin of the American Meteorological Society, 85(3), 381-394. https://doi.org/10.1175/BAMS-85-3-381.

Ruiz-Vásquez, M., Arias, P.A., Martinez, A. and Espinoza, J.C. (2020) Effects of Amazon basin deforestation on regional atmospheric circulation and water vapor transport towards tropical South America. Climate Dynamics, 54, 4169-4189. https://doi. org/10.1007/s00382-020-05223-4.

Salati, E. and Nobre, C.A. (1991) Possible climatic impacts of tropical deforestation. Climatic Change, 19(1-2), 177-196. https:// doi.org/10.1007/BF00142225. 
Salati, E. and Vose, P.B. (1984) Amazon Basin: a system in equilibrium. Science, 225(4658), 129-138. https://doi.org/10.1126/ science.225.4658.129.

Salazar, L.F. and Nobre, C.A. (2010) Climate change and thresholds of biome shifts in Amazonia. Geophysical Research Letters, 37(17), 1-5. https://doi.org/10.1029/2010GL043538.

Sampaio, G., Nobre, C., Costa, M.H., Satyamurty, P., SoaresFilho, B.S. and Cardoso, M. (2007) Regional climate change over eastern Amazonia caused by pasture and soybean cropland expansion. Geophysical Research Letters, 34(17), 1-7. https://doi.org/10.1029/2007GL030612.

Seiler, C., Hautes, R.W.A. and Kabat, P. (2013) Climate variability and trends in Bolivia. Journal of Applied Meteorology and Climatology, 52, 130-146. https://doi.org/10.1175/JAMC-D-12-0105.1.

Sierra, J.P., Junquas, C., Espinoza, J.C., Segura, H., Condom, T., Andrade, M., Molina-Carpio, J., Ticona, L., Mardoñez, V., Blacutt, L., Polcher, J., Rabatel, A. and Sicart, J.E. (2021) Deforestation impacts on Amazon-Andes hydroclimatic connectivity. Climate Dynamics. https://doi.org/10.1007/s00382-021-06025-y.

Song, F., Leung, L.R., Lu, J. and Dong, L. (2018) Seasonally dependent responses of subtropical highs and tropical rainfall to anthropogenic warming. Nature Climate Change, 8(9), 787-792. https://doi.org/10.1038/s41558-018-0244-4.

Spera, S.A., Galford, G.L., Coe, M.T., Macedo, M.N. and Mustard, J. F. (2016) Land-use change affects water recycling in Brazil's last agricultural frontier. Global Change Biology, 22(10), 3405-3413. https://doi.org/10.1111/gcb.13298.

Spracklen, D.V., Arnold, S.R. and Taylor, C.M. (2012) Observations of increased tropical rainfall preceded by air passage over forests. Nature, 489(7415), 282-285. https://doi.org/10.1038/nature11390.

Spracklen, D.V. and Garcia-Carreras, L. (2015) The impact of Amazonian deforestation on Amazon basin rainfall. Geophysical Research Letters, 42(21), 9546-9552. https://doi.org/10.1002/2015GL066063.

Staal, A., Tuinenburg, O.A., Bosmans, J.H.C., Holmgren, M., van Nes, E.H., Scheffer, M., Zemp, D.C. and Dekker, S.C. (2018) Forest-rainfall cascades buffer against drought across the Amazon. Nature Climate Change, 8(6), 539-543. https://doi.org/10. 1038/s41558-018-0177-y.

Sud, Y.C., Walker, G.K., Kim, J.-H., Liston, G.E., Sellers, P.J. and Lau, W.K.-M. (1996) Biogeophysical consequences of a tropical deforestation scenario: a GCM simulation study. Journal of Climate, 9(12), 3225-3247. https://doi.org/10.1175/1520-0442 (1996)009<3225:BCOATD>2.0.CO;2.

Vera, C., Silvestri, G., Liebmann, B. and González, P. (2006) Climate change scenarios for seasonal precipitation in South America from IPCC-AR4 models. Geophysical Research Letters, 33(13), L13707. https://doi.org/10.1029/2006GL025759.

von Randow, C., Manzi, A.O., Kruijt, B., de Oliveira, P.J., Zanchi, F. B., Silva, R.L., Hodnett, M.G., Gash, J.H.C., Elbers, J.A., Waterloo, M.J., Cardoso, F.L. and Kabat, P. (2004) Comparative measurements and seasonal variations in energy and carbon exchange over forest and pasture in South West Amazonia. Theoretical and Applied Climatology, 78(1-3), 5-26. https://doi. org/10.1007/s00704-004-0041-z.

von Randow, R.C.S., von Randow, C., Hutjes, R.W.A., Tomasella, J. and Kruijt, B. (2012) Evapotranspiration of deforested areas in central and southwestern Amazonia. Theoretical and Applied Climatology, 109(1-2), 205-220. https://doi.org/10.1007/s00704011-0570-1.

Wang, D., Zhao, J., Tang, Y. and Sivapalan, M. (2015) A thermodynamic interpretation of Budyko and L'vovich formulations of annual water balance: proportionality hypothesis and maximum entropy production. Water Resources Research, 51(4), 3007-3016. https://doi.org/10.1002/2014WR016857.

Wang, J., Chagnon, F.J.F., Williams, E.R., Betts, A.K., Renno, N.O., Machado, L.A.T., Bisht, G., Knox, R. and Bras, R.L. (2009) Impact of deforestation in the Amazon basin on cloud climatology. Proceedings of the National Academy of Sciences of the United States of America, 106(10), 3670-3674. https://doi.org/ 10.1073/pnas.0810156106.

Wang, X.S. and Zhou, Y. (2016) Shift of annual water balance in the Budyko space for catchments with groundwater-dependent evapotranspiration. Hydrology and Earth System Sciences, 20(9), 3673-3690. https://doi.org/10.5194/hess-20-3673-2016.

Wongchuig, S., Paiva, R., Espinoza, J.C. and Collischonn, W. (2017) Multi-decadal hydrological retrospective: case study of Amazon floods and droughts. Journal of Hydrology, 549, 667-684. https://doi.org/10.1016/j.jhydrol.2017.04.019.

Wright, J.S., Fu, R., Worden, J.R., Chakraborty, S., Clinton, N.E., Risi, C., Sun, Y. and Yin, L. (2017) Rainforest-initiated wet season onset over the southern Amazon. Proceedings of the National Academy of Sciences of the United States of America, 114(32), 8481-8486. https://doi.org/10.1073/pnas.1621516114.

Xu, X., Jia, G., Zhang, X., Riley, W.J. and Xue, Y. (2020) Climate regime shift and forest loss amplify fire in Amazonian forests. Global Change Biology, 26(10), 5874-5885. https://doi.org/10. $1111 /$ gcb.15279.

Yin, L., Fu, R., Zhang, Y.-F., Arias, P.A., Fernando, D.N., Li, W., Fernandes, K. and Bowerman, A.R. (2014) What controls the interannual variation of the wet season onsets over the Amazon? Journal of Geophysical Research: Atmospheres, 119(5), 2314-2328. https://doi.org/10.1002/2013JD021349.

Zemp, D.C., Schleussner, C.-F., Barbosa, H.M.J., Hirota, M., Montade, V., Sampaio, G., Staal, A., Wang-Erlandsson, L. and Rammig, A. (2017) Self-amplified Amazon forest loss due to vegetation-atmosphere feedbacks. Nature Communications, 8(1), 14681. https://doi.org/10.1038/ncomms14681.

Zeng, N. and Neelin, J.D. (1999) A land-atmosphere interaction theory for the tropical deforestation problem. Journal of Climate, 12(2-3), 857-872. https://doi.org/10.1175/1520-0442(1999)012 $<0857$ :alaitf $>2.0$. co;2.

Zhang, Y., Peña-Arancibia, J.L., McVicar, T.R., Chiew, F.H.S., Vaze, J., Liu, C., Lu, X., Zheng, H., Wang, Y., Liu, Y.Y., Miralles, D.G. and Pan, M. (2016) Multi-decadal trends in global terrestrial evapotranspiration and its components. Scientific Reports, 6, 19124. https://doi.org/10.1038/srep19124.

\section{SUPPORTING INFORMATION}

Additional supporting information may be found in the online version of the article at the publisher's website.

How to cite this article: Wongchuig, S., Espinoza, J. C., Condom, T., Segura, H., Ronchail, J., Arias, P. A., Junquas, C., Rabatel, A., \& Lebel, T. (2021). A regional view of the linkages between hydro-climatic changes and deforestation in the Southern Amazon. International Journal of Climatology, 1-19. https://doi.org/10.1002/joc.7443 